Check for updates

Cite this: RSC Adv., 2019, 9, 3320

Received 27th November 2018 Accepted 18th January 2019

DOI: $10.1039 / c 8 r a 09763 a$

rsc.li/rsc-advances

\section{Experimental and theoretical evaluation on the antioxidant activity of a copper(II) complex based on lidocaine and ibuprofen amide-phenanthroline agents $\dagger$}

\author{
Leila Tabrizi, (D) $\dagger^{* a}$ Duy Quang Dao (D) $\dagger^{* b}$ and Thuy $A n V u^{c}$
}

A new copper(II) complex, [Cu(LC)(Ibu-phen) $\left(\mathrm{H}_{2} \mathrm{O}_{2}\right]\left(\mathrm{ClO}_{4}\right)_{2}$ ( $\mathrm{LC}$ : lidocaine, Ibu-phen: ibuprofen amidephenanthroline), was synthesized and characterized. The antioxidant activities of the free ligands and the copper(II) complex were evaluated by in vitro experiments and theoretical calculations using density functional theory (DFT). Structures of the ligand Ibu-phen and the complex were identified by ${ }^{1} \mathrm{H}$ and ${ }^{13} \mathrm{C}$ NMR, FT-IR spectroscopies, mass spectrometry, thermogravimetric analysis and elemental analysis. The antioxidant potentials of LC and Ibu-phen ligands as well as copper(II) complex were also evaluated by $\mathrm{DPPH}^{\circ}, \mathrm{ABTS}^{*+}, \mathrm{HO}^{*}$ essays and EPR spectroscopy. The experimental results show that the radical scavenging activity (RSA) at various concentrations is decreased in the following order: copper(॥) complex > ascorbic acid > LC > Ibu-phen. Structural and electronic properties of the studied compounds were also analyzed by DFT approach at the M05-2X/6-311++g(2df,2p)//M05-2X/LanL2DZ level of theory. ESP maps and NPA charge distributions show that the highly negative charge regions found on the $\mathrm{N}$ and $\mathrm{O}$ heteroatoms make these sites more favorable to bind with the central copper ion. Frontier orbital distributions of copper(II) complex indicate that HOMOs are mainly localized at Ibu-phen, while its LUMOs are distributed at LC. Based on natural bond orbitals (NBO) analyses, CU(॥) ion plays as electron acceptor in binding with the two ligands and two water molecules. Thermochemical properties including bond dissociation enthalpy (BDE), ionization energy (IE), electron affinity (EA), proton affinity (PA) characterizing three common antioxidant mechanisms i.e. hydrogen transfer ( $\mathrm{HT}$ ), single electron transfer (SET) and proton loss (PL) were finally calculated in the gas phase and water solvent for two ligands and the copper(II) complex at the same level of theory. As a result, the higher EA and lower BDE and PA values obtained for copper(II) complex show that the complex shows higher antioxidant potential than the free ligands.

\section{Introduction}

Oxidative stress (OS) is a health-threatening process that is involved, at least partially, in the development of several human diseases including different types of atherosclerosis, inflammatory injuries, cardiovascular diseases, cancer,

${ }^{a}$ School of Chemistry, National University of Ireland, Galway, University Road, Galway, H91 TK33, Ireland. E-mail: leila.tabrizi@nuigalway.ie

${ }^{b}$ Institute of Research and Development, Duy Tan University, 03 Quang Trung, Da Nang, 550000, Viet Nam.E-mail: daoduyquang@gmail.com

${ }^{c}$ Faculty of Environment and Chemical Engineering, Duy Tan University, 03 Quang Trung, Da Nang, 550000, Viet Nam

$\dagger$ Electronic supplementary information (ESI) available: ${ }^{1} \mathrm{H},{ }^{13} \mathrm{C}$ NMR spectra of ligand Ibu-phen, mass spectra of ligand Ibu-phen and copper(II) complex. Cartesian coordinates and molecular enthalpies of copper(II) complex structures for different multiplicities from 2 to 8 optimized at M05-2X/LanL2DZ level of theory in the gas phase. See DOI: 10.1039/c8ra09763a

\$ These authors contributed equally. neurodegenerative diseases, and aging. ${ }^{\mathbf{1 - 5}}$ It can be defined as an imbalance between reactive oxygen species (ROS) and antioxidant levels leading to cell damage and health problems. OS provokes the production of ROS which are generally oxygencontaining radical species such as superoxide anion radicals, hydroxyl radicals or even hydrogen peroxide and singlet oxygen. Reactive nitrogen species (RNS), reactive sulfur species (RSS) could be also generated during oxidative stress. Antioxidants moderate ROS levels in cells and can therefore attend as a type of defensive medicine for human diseases caused by OS.

The transition metal ions can endorse an extensive range of coordination numbers, geometries, and oxidation states in comparison with other main group elements. The great potential value of finding or creating new antioxidant classes has already encouraged researchers to study for the metal-derived antioxidants. However, the antioxidant capacity of metal complexes is still not evident. Indeed, several experimental data in the literature reveals that flavonoid complexes are more 
effective radical scavengers than free flavonoids. ${ }^{6}$ The enhanced activity was reported for the $\mathrm{Fe}(\mathrm{II}), \mathrm{Fe}(\mathrm{III}), \mathrm{Cu}(\mathrm{II})$ and $\mathrm{Zn}$ (II) complexes of rutin, epicatechin and dihydroquercetin. ${ }^{7,8}$

On the other hand, the role of flavonoids as pro-oxidant agents, especially in cancer cell lines, has been the subject of research for decades. ${ }^{9-12}$ The complexes of flavonoid compounds with metals like $\mathrm{Cu}$ (II) or Fe(III) have been shown to act as pro-oxidant in forming hydroxyl radical. This trend can be explained by the fact that metal coordination changes the redox potential of ligand and thus affects on its antioxidant capacity. ${ }^{13}$ For example, luteolin $\left(5,7,3^{\prime}, 4^{\prime}\right.$-tetrahydroxyflavone) shows better antioxidant activity than the luteolin-Fe(III) complex in the $\mathrm{DPPH}^{\cdot}$ assay. ${ }^{14}$ Markovic et al. evaluate the relevant interactions of morin and quercetin, as well as their respective iron(III) complexes with $\mathrm{DPPH}^{*}$, tempone, hydroxyl and superoxide radicals..$^{15}$ The authors observe that both quercetin and morin present higher free radical scavenging activity than their corresponding complexes with Fe(III) ion.

Thus, several questions rise from, first, the choice of metal and linker to build the complex which promotes the enhanced antioxidant activity and second, the type of mechanism which favors the improvement of the antioxidant capacity of the metal complex compared to that of their parent components. The lack of an in-deep understanding about the general behavior of metal complexes in this field prompts us to study the antioxidant activity of metal complexes by both experimental and theoretical ways.

The main objective of this work consists of synthesizing a new copper(II) complex based on lidocaine and ibuprofen amide-phenanthroline ligands which hopefully possesses stronger radical scavenging activity in comparison with its ligands, and evaluating their antioxidant activities through experimental assays and computational chemistry approach. It is noteworthy that while seeking for the development of metallodrugs as potent antioxidant agents, $\mathrm{Cu}(\mathrm{II})$ ion appears to us as natural ideal metal candidate. The $\mathrm{Cu}$ (II) is a biologically essential ion that includes positive redox potential in biological electron transfer reactions. Copper complexes have revealed significant performance in antioxidant studies. ${ }^{16-21}$ In addition, lidocaine (LC) is a local anesthetic agent widely used in the clinic therapy which is reported to act as a concentration dependent antioxidant. ${ }^{22}$ Recently, the syntheses and biological properties on the Ni(II), $\mathrm{Co}$ (II), $\mathrm{Ru}(\mathrm{II}), \operatorname{Ir}(\mathrm{III}), \mathrm{Pt}(\mathrm{II})$ and $\mathrm{Pd}(\mathrm{II})$ complexes with lidocaine have been reported for traditional chemotherapy and photodynamic therapy. ${ }^{23-27}$ Ibuprofen is a propionic acid derivative and nonsteroidal anti-inflammatory drug with anti-inflammatory, analgesic and antipyretic effects. Ibuprofen inhibits the activity of cyclo-oxygenase I and II (COX-1 and COX-2), causing a reduced formation of precursors of prostaglandins and thromboxanes. ${ }^{28,29}$

Herein, we report the synthesis and characterization of a new copper(II) complex based on lidocaine and ibuprofen amidephenanthroline agents. The antioxidant activity of the free ligands and copper complex are experimentally evaluated by $\mathrm{DPPH}^{\circ}, \mathrm{ABTS}^{*+}$ and $\mathrm{HO}^{*}$ radicals scavenging assays. A density functional theory (DFT) study based on calculations of thermochemical parameters such as bond dissociation enthalpy
(BDE), ionization energy (IE), electron affinity (EA) and proton affinity (PA) is also performed in the gas phase and water solvent. These parameters allow providing more insight into its free radical scavenging capacity and mechanism.

\section{Methods}

\subsection{Materials and methods}

The ligand Ibu-phen was synthesized under nitrogen atmosphere by standard Schlenk techniques using as-received analytical or HPLC grade solvents and reagents from commercial suppliers..$^{30} \quad$ 2,2'-Azino-bis(3-ethylbenzthiazoline-6sulphonic acid) $\left(\mathrm{ABTS}^{+}\right)$and 2,2-diphenyl-1-picrylhydrazyl (DPPH ${ }^{\circ}$, ascorbic acid and lidocaine were purchased from Sigma-Aldrich.

Fourier transform infrared (FT-IR) spectra were recorded on a PerkinElmer Spectrum 400 (FT-IR/FT-NIR spectrometer) fitted in the $650-3600 \mathrm{~cm}^{-1}$ range. ${ }^{1} \mathrm{H},{ }^{13} \mathrm{C}$ nuclear magnetic resonance (NMR) spectra were recorded on a Bruker-400 $\mathrm{MHz}$ spectrometer at ambient temperature in DMSO- $d_{6}$. Electrospray ionization (ESI) mass spectra were recorded on a Waters LCT Premier XE spectrometer in positive- or negative-ion mode. Elemental analyses were performed with an EA 3000 CHNS. Electron paramagnetic resonance (EPR) spectra (X-band, $0.34 \mathrm{~T}$, $9.5 \mathrm{GHz}$ ) were obtained with a Varian spectrometer, equipped with a variable-temperature facility in the following conditions: 3385.0 Gs field, $20.0 \mathrm{mV}$ power, $100.0 \mathrm{kHz}$ modulation frequency, $1.0 \mathrm{GS}$ amplitude and 300 seconds sweep time. The $g$ values were determined using a DPPH standard. Electronic absorption spectra were obtained on a Shimadzu Lambda- 1600 UV-Vis spectrophotometer. Solid state UV-Vis diffused reflectance spectra were recorded with a Shimadzu 2450 PC UV-Vis recording spectrophotometer. Thermogravimetric analysis (TGA) of the copper(II) complex was obtained on a STA625 thermal analyzer from Rheometric Scientific by collecting $10 \mathrm{mg}$ of the compound in nitrogen atmosphere. The heating rate was kept constant at $10{ }^{\circ} \mathrm{C} \mathrm{min}^{-1}$.

\subsection{Synthesis of ibuprofen amide-phenanthroline (Ibu- phen)}

To a solution of ibuprofen $(0.661 \mathrm{~g}, 3.2 \mathrm{mmol})$ in DMF $(10 \mathrm{~mL})$ was added $N, N$-diisopropylethylamine (DIEA) $(1.251 \mathrm{~g}, 9.7$ mmol). The mixture was cooled to $0{ }^{\circ} \mathrm{C}$ and treated with $\mathrm{N}$-(3dimethylaminopropyl)- $N^{\prime}$-ethylcarbodiimide hydrochloride (EDC-HCl) (1.2 g, $6.5 \mathrm{mmol})$, 1-hydroxybenzotriazole hydrate (HOBt $\left.\cdot x \mathrm{H}_{2} \mathrm{O}\right)(0.879 \mathrm{~g}, 6.5 \mathrm{mmol})$ and 1,10-phenanthrolin-5amine $(0.957 \mathrm{~g}, 4.9 \mathrm{mmol})$. The reaction was stirred at room temperature for $15 \mathrm{~h}$ under nitrogen. After completion, the mixture was diluted with water $(50 \mathrm{~mL})$ and extracted with dichloromethane $(70 \mathrm{~mL})$. The organic layer was dried with sodium sulfate $\left(\mathrm{Na}_{2} \mathrm{SO}_{4}\right)$ and concentrated in vacuum. The resulting material was purified by silica gel column chromatography (3\% methanol/dichloromethane) to provide the product as orange solids ( $1.058 \mathrm{~g}, 86 \%$ yield, $3.2 \mathrm{mmol}$ ). Anal. calc. (\%) for $\mathrm{C}_{25} \mathrm{H}_{25} \mathrm{~N}_{3} \mathrm{O}$ (383.1998): C, 78.30; H, 6.57; N, 10.96; found (\%): C, 78.22; H, 6.51; N, 10.90. TOF-MS: 384.2076 [M + 
$\mathrm{H}]^{+}$. FT-IR: $\nu 3219$ (NH stretch), $1679(\mathrm{C}=\mathrm{O}$ stretch $) \mathrm{cm}^{-1} \cdot{ }^{1} \mathrm{H}$ NMR (DMSO- $\left.d_{6}\right): \delta 9.02(\mathrm{~s}, 1 \mathrm{H}), 8.68(\mathrm{~m}, 2 \mathrm{H}, \mathrm{H}-\mathrm{Ar}), 8.01(\mathrm{~m}, 1 \mathrm{H}$, $\mathrm{H}-\mathrm{Ar}$ ), 7.69 (m, 1H, H-Ar), 7.17 (t, 2H, H-Ar, $J=5.0 \mathrm{~Hz}), 7.08(\mathrm{t}$, $2 \mathrm{H}, \mathrm{H}-\mathrm{Ar}, J=5.0 \mathrm{~Hz}$ ), 6.87 (s, 1H, H-Ar), 3.50 (q, 1H, H-6, J=5.0 $\mathrm{Hz}$ ), 2.36 (d, 2H, H-3, J=10.0 Hz), 1.87 (m, 1H, H-2), 1.42 (d, 3H, $\mathrm{H}-7, J=10.0 \mathrm{~Hz}), 0.90(\mathrm{~d}, 6 \mathrm{H}, \mathrm{H}-1, J=10.0 \mathrm{~Hz}) \cdot{ }^{13} \mathrm{C} \mathrm{NMR}$ $\left(\mathrm{DMSO}-d_{6}\right)$ : $\delta 174.9(\mathrm{C}=\mathrm{O}), 160.0(\mathrm{Ar}), 152.2(\mathrm{Ar}), 148.1(\mathrm{Ar})$, 142.3 (Ar), 136.0 (Ar), 133.1 (Ar), 129.9 (Ar), 128.3 (Ar), 125.7 (Ar), 123.9 (Ar), 122.1 (Ar), 44.6, 29.1, 24.3, 17.1.

\subsection{Synthesis of the complex $\left[\mathrm{Cu}(\mathrm{LC})(\mathrm{Ibu}-\mathrm{phen})\left(\mathrm{H}_{2} \mathrm{O}\right)_{2}\right]\left(\mathrm{ClO}_{4}\right)_{2}$}

A solution of $\mathrm{Cu}\left(\mathrm{ClO}_{4}\right)_{2} \cdot 6 \mathrm{H}_{2} \mathrm{O}(0.37 \mathrm{~g}, 1 \mathrm{mmol})$ in acetonitrile (5 $\mathrm{mL}$ ) was added to a solution of lidocaine (LC) $(0.234 \mathrm{~g}, 1 \mathrm{mmol})$ in acetonitrile $(5 \mathrm{~mL})$. The mixture was stirred for $10 \mathrm{~min}$, then a solution of ibuprofen amide-phenanthroline (Ibu-phen) $(0.383 \mathrm{~g}, 1 \mathrm{mmol})$ in dichloromethane $(10 \mathrm{~mL})$ was added dropwise at $50{ }^{\circ} \mathrm{C}$ and the mixture was left stirring for $24 \mathrm{~h}$. The mixture was filtered and the filtrate was dried under vacuum giving desired complex as a greenish-orange solid (660 mg, 72\% yield, $1 \mathrm{mmol}$ ). Anal. calc. (\%) for $\mathrm{C}_{39} \mathrm{H}_{51} \mathrm{Cl}_{2} \mathrm{CuN}_{5} \mathrm{O}_{12}$ (916.3005): C, 51.12; H, 5.61; N, 7.64; found (\%): C, 51.07; H, 5.59; N, 7.59. TOF-MS: $815.2722\left[\mathrm{M}-\left(\mathrm{ClO}_{4}\right)\right]^{+}$. FT-IR: $\nu 3356\left(\mathrm{H}_{2} \mathrm{O}\right), 3227(\mathrm{NH}$ stretch), 1679, $1648 \quad(\mathrm{C}=\mathrm{O}$ stretch $), 1097\left(\mathrm{ClO}_{4}{ }^{-}\right), 994$ $\left(\mathrm{ClO}_{4}^{-}\right) \mathrm{cm}^{-1}$.

Warning: perchlorate salts may be explosive.

\subsection{DPPH $^{\circ}, \mathrm{ABTS}^{*+}$ and $\mathrm{HO}^{\circ}$ radicals scavenging assay}

2.4.1. DPPH ${ }^{\circ}$. The $\mathrm{DPPH}^{\circ}$ assay was carried out using the reported method with some modifications. ${ }^{31}$ To a $0.1 \mathrm{mM}$ solution of $\mathrm{DPPH}^{*}$ in $\mathrm{MeOH}(2 \mathrm{~mL})$, was added a 5-15 $\mu \mathrm{M}$ solution of the inquired antioxidant in methanol $(20 \mu \mathrm{L})$ and the reaction mixture was shaken vigorously. The reduction of $\mathrm{DPPH}^{\circ}$ absorbance was followed by monitoring at $517 \mathrm{~nm}$ every $5 \mathrm{~min}$ for about $35 \mathrm{~min}$. As a control, the absorbance of the blank solution of $\mathrm{DPPH}^{*}(2 \mathrm{~mL})$ was also registered at $517 \mathrm{~nm}$.

2.4.2. ABTS $^{*+}$. ABTS $^{\cdot+}$ radical scavenging activity was based on the reported method. ${ }^{32}$ Briefly, ABTS powder $(54.2 \mathrm{mg}$ ) was dissolved in $10 \mathrm{~mL}$ of phosphate buffer ( $5 \mathrm{mM}, \mathrm{pH} 7.0) .1 .0 \mathrm{~g}$ of $\mathrm{MnO}_{2}$ was added and the resulting solution was incubated at room temperature for $30 \mathrm{~min}$ to generate a green color $\mathrm{ABTS}^{\circ+}$ solution. The solution was centrifuged for $5 \mathrm{~min}$ and filtered to remove all excess of $\mathrm{MnO}_{2}$. The filtrate was diluted with phosphate buffer until the absorbance of solution measured at $723 \mathrm{~nm}$ equal to $0.70 \pm 0.01$ (final concentration $1 \mathrm{mM}$ ). Different concentrations (5-15 $\mu \mathrm{M})$ of the inquired antioxidant $(20 \mu \mathrm{L})$ were added to $2 \mathrm{~mL}$ of $\mathrm{ABTS}^{\circ+}$ solution and incubated for $10 \mathrm{~min}$ at room temperature. The decrease of absorbance was monitored at $734 \mathrm{~nm}$ after $10 \mathrm{~min}$.

2.4.3. HO'. Hydroxyl radical $\left(\mathrm{HO}^{\circ}\right)$ scavenging activity was investigated based on the method reported in literature. ${ }^{33}$ Briefly, different concentrations of $(5-15 \mu \mathrm{M})$ of the inquired antioxidant $(20 \mu \mathrm{L})$ were added to the reaction mixture, which contained $8 \mathrm{mM} \mathrm{FeSO}_{4}(0.25 \mathrm{~mL}), 6 \mathrm{mM} \mathrm{H}_{2} \mathrm{O}_{2}(0.4 \mathrm{~mL}), 0.25 \mathrm{~mL}$ distilled water and $20 \mathrm{mM}$ sodium salicylate $(0.1 \mathrm{~mL})$ (final concentration $1 \mathrm{mM}$ ). Then the reaction system was incubated at $37{ }^{\circ} \mathrm{C}$ for $1 \mathrm{~h}$. Absorbance value was determined at $562 \mathrm{~nm}$.
For all assays, the radical scavenging activity (RSA) was calculated using the following equation:

$$
\operatorname{RSA}(\%)=\left(1-\frac{A}{A_{0}}\right) \times 100
$$

where $A_{0}$ is the absorbance of the control, and $A$ is the absorbance of test sample.

\subsection{Electron paramagnetic resonance (EPR) measurements for $\mathrm{DPPH}^{\bullet}, \mathrm{ABTS}^{++}$and HO` radicals scavenging assay}

EPR spin trapping were applied to detect the $\mathrm{DPPH}^{*}$ radical scavenging activity by LC, Ibu-phen, copper(II) complex and ascorbic acid as previously described procedure. ${ }^{34}$ A solution of $5 \mu \mathrm{M}$ or $15 \mu \mathrm{M}$ of inquired antioxidant in $\mathrm{EtOH}(60 \mu \mathrm{L})$ was added to a $60 \mu \mathrm{M}$ solution of DPPH in EtOH $(60 \mu \mathrm{L})$. After mixing vigorously for $10 \mathrm{~s}$, the solution was transferred into a $100 \mu \mathrm{L}$ quartz capillary tube, and the spin adduct was measured after 2 min.

For $\mathrm{ABTS}^{++}$radicals scavenging assay, a solution of $5 \mu \mathrm{M}$ or $15 \mu \mathrm{M}$ of inquired antioxidant in $\mathrm{EtOH}(50 \mu \mathrm{L})$ was added to a 50 $\mu \mathrm{M}$ solution of $\mathrm{ABTS}^{-+}$in $\mathrm{EtOH}(50 \mu \mathrm{L})$. After mixing vigorously for $5 \mathrm{~s}$, the solution was transferred into a $100 \mu \mathrm{L}$ quartz capillary tube, and the spin adduct was measured after 3 minutes.

For $\mathrm{HO}^{\star}$ scavenging assay, the Fenton reagents were used to test the ability of antioxidants. ${ }^{35}$ The reaction mixture contained $10 \mathrm{mM}$ DMPO, $100 \mu \mathrm{M} \mathrm{FeSO}_{4}, 10 \mathrm{mM} \mathrm{H}_{2} \mathrm{O}_{2}$ without and with the presence of each studied antioxidant. After stirring for $5 \mathrm{~s}$, $50 \mu \mathrm{L}$ of the mixture were transferred into a $100 \mu \mathrm{L}$ disposal capillary tube. The EPR spectrum was recorded after 2.5 minutes.

The radical scavenging activity (RSA) was calculated using the following equation:

$$
\operatorname{RSA}(\%)=\left(1-\frac{H}{H_{0}}\right) \times 100
$$

where $H$ and $H_{0}$ were the height of the third resonance peak for test sample and the control, respectively.

\subsection{Statistical analyses}

Obtained data are presented as averaged value \pm standard deviation (SD). Statistical analyses were carried out using ANOVA and a Student's $t$-test and the Kruskal-Wallis and Mann-Whitney U-test (SPSS for Windows version 10.0). Differences were considered significant if $p<0.05$.

\section{Computational methods}

All computational calculations were performed by employing GAUSSIAN 09 RevE.01. ${ }^{36}$ Geometry optimization and frequency calculations for LC, Ibu-phen and copper complex were investigated using M05-2X functional which has been suggested by its authors for estimation of thermodynamic parameters. ${ }^{37}$ All geometry optimizations were realized using the LanL2DZ basis set $^{38}$ without any symmetry constraints. ${ }^{39}$ LanL2DZ is known as an appropriate basis set to describe electronic structure for 
compounds of transition metals. Calculations performing at this basis set provided acceptable correlations with some experimental results. ${ }^{40}$ The geometrical structures of copper(II) complex with different spin configurations were examined and the lowest energy one was kept for further analysis. The optimization was followed by a single-point calculation at the M052X/6-311++G(2df,2p) model chemistries.

Natural bond orbital (NBO) analyses were also performed in order to provide more insight into electron density transfer between the two ligands and $\mathrm{Cu}(\mathrm{II})$ ion. The extend of these interactions was quantified by means of the second order perturbation energy values $\left(E^{(2)}\right)$ estimated from the following equation: ${ }^{41}$

$$
E^{(2)}=-q_{\mathrm{i}} \frac{\left(F_{\mathrm{i}, \mathrm{j}}\right)^{2}}{\varepsilon_{\mathrm{j}}-\varepsilon_{\mathrm{i}}}
$$

where $\varepsilon_{\mathrm{j}}-\varepsilon_{\mathrm{i}}$ was the energy difference between donor and acceptor $\mathrm{i}$ and $\mathrm{j}$ NBO orbitals and $F_{\mathrm{i}, \mathrm{j}}$ is the Fock matrix element between $i$ and $j$ NBO orbitals.

Natural population charges for heavy atoms including $\mathrm{C}, \mathrm{N}, \mathrm{O}$ and $\mathrm{Cu}$, electrostatic potential map and frontier orbitals distributions were also analysed for further prediction of local reactivity.

Three common mechanisms including hydrogen atom transfer (HAT), single electron transfer (SET) and proton loss (PL) were considered in this study to analyse the antioxidant potential of the ligands and copper(II) complex.

- Hydrogen atom transfer (HAT):

$$
\text { Anti }-\mathrm{H} \rightarrow(\text { Anti) })^{\bullet}+\mathrm{H}^{\cdot},(\mathrm{BDE})
$$

- Single electron transfer (SET):

$$
\begin{aligned}
& \text { Anti }-\mathrm{H} \rightarrow(\text { Anti }-\mathrm{H})^{\bullet^{+}}+\mathrm{e}^{-},(\text {IE) } \\
& \text { Anti }-\mathrm{H}+\mathrm{e}^{-} \rightarrow(\text { Anti }-\mathrm{H})^{\cdot-},(\text { EA })
\end{aligned}
$$

- Proton loss (PL):

$$
\text { Anti }-\mathrm{H} \rightarrow(\text { Anti })^{-}+\mathrm{H}^{+},(\mathrm{PA})
$$

The thermochemical properties characterizing the above mechanisms including bond dissociation enthalpy (BDE), adiabatic ionization energy (IE) and electron affinity (EA) and proton affinity (PA) were systematically calculated in the gas phase at $298.15 \mathrm{~K}$ and $1 \mathrm{~atm}$.

$$
\begin{gathered}
\mathrm{BDE}=H(\text { Anti })+H\left(\mathrm{H}^{\cdot}\right)-H(\text { Anti }-\mathrm{H}) \\
\mathrm{IE}=H\left(\text { Anti }-\mathrm{H}^{\cdot+}\right)+H\left(\mathrm{e}^{-}\right)-H(\text { Anti }-\mathrm{H}) \\
\mathrm{EA}=H(\text { Anti }-\mathrm{H})+H\left(\mathrm{e}^{-}\right)-H\left(\text { Anti }-\mathrm{H}^{\cdot-}\right) \\
\mathrm{PA}=H(\text { Anti })^{-}+H\left(\mathrm{H}^{+}\right)-H(\text { Anti }-\mathrm{H})
\end{gathered}
$$

where $H$ was the total enthalpy of the studied species at $298.15 \mathrm{~K}$ and is usually estimated from the following expression:

$$
H=E_{0}+\mathrm{ZPE}+H_{\text {trans }}+H_{\mathrm{rot}}+H_{\mathrm{vib}}+R T,
$$

$H_{\text {trans }}, H_{\text {rot }}$ and $H_{\text {vib }}$ were the translational, rotational, and vibrational contributions to the enthalpy, respectively. $E_{0}$ was the total energy at $0 \mathrm{~K}$, and ZPE was the zero-point vibrational energy.

The enthalpy value for the hydrogen atom $\left(\mathrm{H}^{\circ}\right)$ was calculated at the same level of theory. The enthalpies in the gas phase of proton $\left(\mathrm{H}^{+}\right)$being 0.00236 Hartree $(5 / 2 R T$, the value of an ideal gas) has widely been accepted. ${ }^{42}$ The effect of water on the thermochemical properties was also investigated based on integral equation formalism of the polarizable continuum model (IEF-PCM) at the same level of theory. ${ }^{43}$ Solvation enthalpies of proton and electron in water solvent were calculated using computational approach proposed by Markovic et al. (2016). ${ }^{44}$ When a proton or an electron is surrounded by the water molecules, it will bind to the water molecule to form a positive or a negative charged particle, $\mathrm{H}_{2} \mathrm{O}_{\text {sol }}{ }^{+}$or $\mathrm{H}_{2} \mathrm{O}_{\text {sol }}{ }^{-}$, respectively. These charged particles are then embedded in a dielectric continuum. This computational approach has been accepted and widely used in several works in the field of antioxidant compounds. ${ }^{4546}$ As a result, the enthalpies of proton and electron in water were equal to -981.8 and $-48.3 \mathrm{~kJ} \mathrm{~mol}^{-1}$, respectively.

\section{Results and discussion}

\subsection{Synthesis and characterization}

The ligand ibuprofen amide-phenanthroline (Ibu-phen) was synthetized using a slightly modified literature method. ${ }^{30}$ Coupling of ibuprofen with 1,10-phenanthrolin-5-amine was carried out using $N$-(3-dimethylaminopropyl)- $N^{\prime}$-ethylcarbodiimide hydrochloride (EDC-HCl), $N, N$-diisopropylethylamine (DIEA) and 1-hydroxybenzotriazole hydrate $\left(\mathrm{HOBt} \cdot x \mathrm{H}_{2} \mathrm{O}\right)$ in DMF via the procedure outlined in the Experimental section (Scheme 1). Good yield and pure ligand of Ibu-phen are obtained when the reaction is run at a temperature range of about $0{ }^{\circ} \mathrm{C}$ to room temperature. The ligand Ibu-phen is highly soluble in methanol but insoluble in other solvents such as water, benzene, toluene, acetone, ether, acetonitrile, dichloromethane and chloroform. The success of the coupling reaction is demonstrated in the ${ }^{1} \mathrm{H}$ NMR spectrum by the disappearance of the signals of amino proton of the starting 1,10-phenanthrolin5 -amine at $6.16 \mathrm{ppm}$ and of $\mathrm{COOH}$ proton of ibuprofen at 12.21 ppm (Fig. S1 and S2 of the ESI $\dagger$ ). ${ }^{4748}$

The copper(II) complex was obtained by reacting $\mathrm{Cu}\left(\mathrm{ClO}_{4}\right)_{2}$ $\cdot 6 \mathrm{H}_{2} \mathrm{O}$ with ibuprofen amide-phenanthroline (Ibu-phen) and lidocaine (LC) in acetonitrile/dichloromethane $(1: 1)$ at $50{ }^{\circ} \mathrm{C}$ (Scheme 1). The copper(II) complex is soluble in methanol, DMF, DMSO, and water but insoluble in other organic solvents. The mass spectrum of ligand Ibu-phen shows peaks of $[\mathrm{M}+\mathrm{H}]^{+}$ centered at $\mathrm{m} / \mathrm{z} 384.2076$ and 385.1132 while in the spectrum of copper complex we observed major isotopes of the fragment of $\left[\mathrm{M}-\left(\mathrm{ClO}_{4}\right)\right]^{+}$at $\mathrm{m} / z$ 815.2722 and 817.2345 (Fig. S3 and $\mathrm{S} 4$ of the $\mathrm{ESI} \dagger)$. In the IR spectrum of copper complex, the $\nu(\mathrm{C}=\mathrm{O})$ bands were shifted to lower frequencies at $1648 \mathrm{~cm}^{-1}\left(1662 \mathrm{~cm}^{-1}\right.$ in LC) due to the coordination of oxygen atom to the copper ion. ${ }^{24}$ The copper(II) complex shows broad $\nu\left(\mathrm{H}_{2} \mathrm{O}\right)$ band at $3356 \mathrm{~cm}^{-1}$ 
<smiles>CC(C)Cc1ccc(C(C)C(=O)O)cc1</smiles><smiles>CC(C)Cc1ccc(C(C)C(=O)Nc2cc3cccnc3c3ncccc23)cc1</smiles>
Ibu-phen

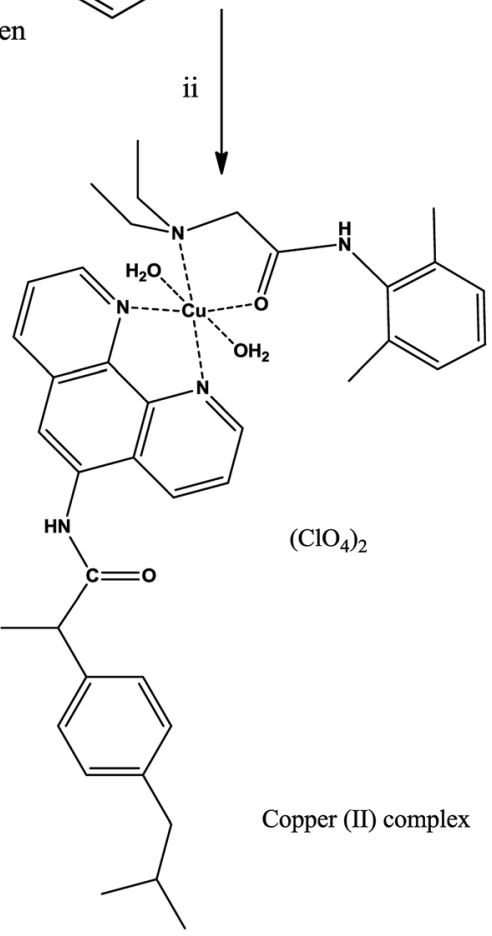

Scheme 1 Synthetic pathways of the ligand Ibu-phen and the copper(II) complex. Reagents and conditions: (i) EDC, HOBt, DIEA, DMF, $0{ }^{\circ} \mathrm{C}$ to rt., $15 \mathrm{~h}, 86 \%$; (ii) $\mathrm{Cu}\left(\mathrm{ClO}_{4}\right)_{2} \cdot 6 \mathrm{H}_{2} \mathrm{O}, \mathrm{CH}_{3} \mathrm{CN}: \mathrm{CH}_{2} \mathrm{Cl}_{2} 1: 1,50{ }^{\circ} \mathrm{C}$, $24 \mathrm{~h}, 72 \%$.

in coherence with the presence of coordinated water (Fig. S5-S7 of the ESI $\dagger){ }^{49}$

\subsection{UV-Vis spectroscopy studies and stability in solution}

The UV-Vis spectrum of the copper(II) complex in the solid state (Fig. S8†) showed two bands at $408 \mathrm{~nm}$ and $702 \mathrm{~nm}$. The broadness of the band at $702 \mathrm{~nm}$ showed the three transitions ${ }^{2} \mathrm{~B}_{1 \mathrm{~g}} \rightarrow{ }^{2} \mathrm{~A}_{1 \mathrm{~g}}\left(\nu_{1}\right),{ }^{2} \mathrm{~B}_{1 \mathrm{~g}} \rightarrow{ }^{2} \mathrm{~B}_{2 \mathrm{~g}}\left(\nu_{2}\right)$ and ${ }^{2} \mathrm{~B}_{1 \mathrm{~g}} \rightarrow{ }^{2} \mathrm{E}_{\mathrm{g}}\left(\nu_{3}\right)$, due to dynamic Jahn-Teller distortion and suggested the distorted octahedral geometry $\left(D_{4 \mathrm{~h}}\right)$ around $\mathrm{Cu}(\mathrm{II})$ center. ${ }^{50}$ In the DMSO solution, the absorbance bands were observed at the same wavelength, indicating that the copper(II) complex is structurally stable in DMSO solution and no significant change in the coordination environment of the $\mathrm{Cu}(\mathrm{II})$ ion was observed.

In addition, the stability of copper(II) complex was monitored over $72 \mathrm{~h}$ in DMSO solution at room temperature (Fig. S9†). The results did not show any significant change in either the intensity or the position of the absorption bands, which confirmed the stability of the copper(II) complex in DMSO solution.

\subsection{Electron paramagnetic resonance (EPR) spectroscopy of copper(II) complex}

The X-band EPR spectra of the copper(II) complex in the solid state and in DMSO solution were recorded at both $298 \mathrm{~K}$ and 77 $\mathrm{K}$ to clarify the coordination environment around $\mathrm{Cu}$ (II) center. The EPR spectra of the copper(II) complex are displayed in Fig. 1. The spectral parameters and their assignments are presented in Table 1.

The EPR spectra for both the solid sample and in DMSO solution have the same features. The EPR spectrum of the copper(II) complex both at $298 \mathrm{~K}$ or $77 \mathrm{~K}$ as solid or in DMSO solution, shows the distorted octahedral symmetry center, for which the evaluated parameters are: $g_{\|}>g_{\perp}$, and $A_{\|}=141-149$ $\times 10^{-4} \mathrm{~cm}^{-1}$. The obtained $A_{\|}$value for copper(II) complex is comparable with $A_{\|}$found for six-coordinate complexes of distorted octahedral geometries, such as the bis(pyridine-2,6diimine) $\mathrm{Cu}$ (II) complex $\left(A_{\|}=145 \times 10^{-4} \mathrm{~cm}^{-1}\right)$, or the $[\mathrm{Cu}(\mathrm{NOTA})]^{-}$complex (NOTA $=1,4,7$-triazacyclononane-1,4,7-

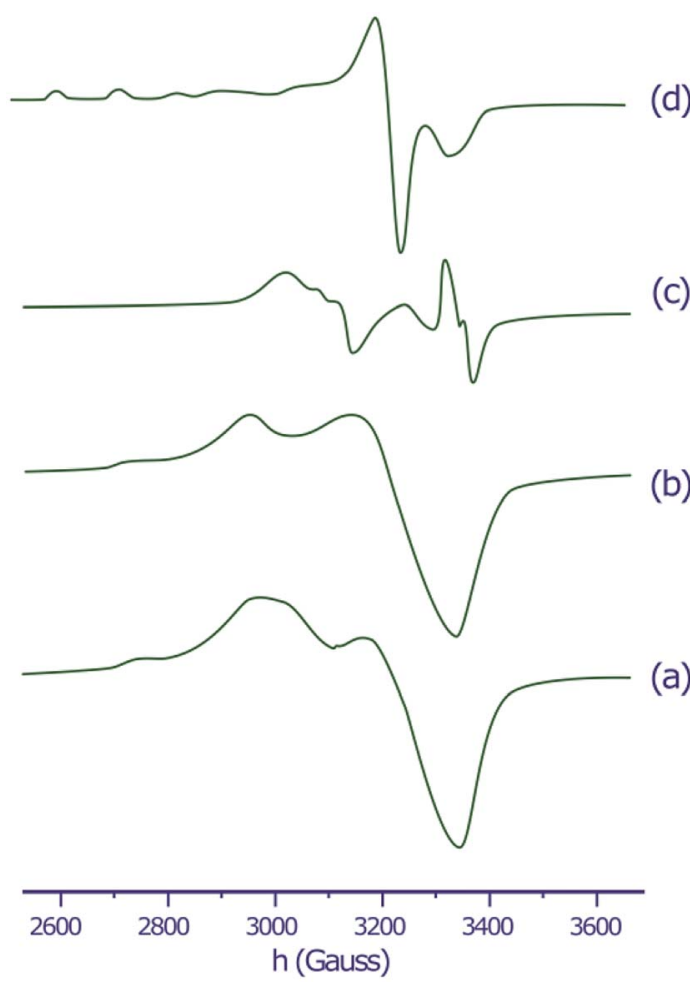

Fig. 1 EPR spectra of the copper(I) complex in the solid state at $298 \mathrm{~K}$ (a), in the solid state at $77 \mathrm{~K}$ (b), in DMSO solution at $298 \mathrm{~K}$ (c) and in DMSO solution at $77 \mathrm{~K}(\mathrm{~d})$. 
Table 1 EPR spectral parameters of the copper(II) complex

\begin{tabular}{lcccc}
\hline $\begin{array}{l}\text { Copper(II) } \\
\text { complex }\end{array}$ & Solid (298 K) & Solid (77 K) & DMSO $(298 \mathrm{~K})$ & DMSO (77 K) \\
\hline$g_{\|}$ & 2.374 & 2.371 & 2.412 & 2.403 \\
$g_{\perp}$ & 2.092 & 2.088 & 2.098 & 2.095 \\
${ }^{a} A_{\|}$ & 148 & 142 & 149 & 141 \\
${ }^{b} G$ & 4.144 & 4.302 & 4.281 & 4.322
\end{tabular}

${ }^{a} A_{\|}$values have $10^{-4} \mathrm{~cm}^{-1}$ units. ${ }^{b} G=\left(g_{\|}-2.0023\right) /\left(g_{\perp}-2.0023\right)$.

triacetate) $\left(A_{\|}=149.5 \times 10^{-4} \mathrm{~cm}^{-1}\right) .{ }^{51,52}$ The $g_{\|}>g_{\perp}>2.0023$ observed for the copper(II) complex is consistent with a cop$\operatorname{per}(\mathrm{II})\left(\mathrm{d}^{9}\right)$ ion in axial symmetry and the unpaired electron in the $\mathrm{d}_{x^{2}-y^{2}}$ orbital. ${ }^{53}$ It was reported that $g_{\|}$values vary in the ranges of 2.3-2.4 and 2.2-2.3 for complexes owning $\mathrm{Cu}-\mathrm{O}$ and $\mathrm{Cu}-\mathrm{N}$ bonds, respectively. ${ }^{54-57}$ Therefore, $g_{\|}$values $2.37-2.41$ found for our copper(II) complex are in agreement with both $\mathrm{Cu}-\mathrm{O}$ and $\mathrm{Cu}-\mathrm{N}$ bonds in this complex. A minor variation in the point symmetry from octahedral geometry is observed for mixed copper-nitrogen and copper-oxygen system. ${ }^{57}$ The calculated geometric parameter $G$ using the equation $G=\left(g_{\|}-2.0023\right) /\left(g_{\perp}\right.$ - 2.0023) for the copper(II) complex is higher than 4 , this predicts that the exchange interaction between the metal centers is minor. ${ }^{58}$

\subsection{Thermal analysis}

By using thermogravimetric analysis (TGA), we can get information whether the water molecules are inside or outside the inner coordination sphere of the central metal ion. The temperature range at $90-140{ }^{\circ} \mathrm{C}$ corresponds to the weak binding of water and region $150-220{ }^{\circ} \mathrm{C}$ corresponds to the strong binding of water (or coordinated water molecules). ${ }^{59}$ Analysis of the TGA and differential thermogravimetric analysis (DTG) curves of the copper(II) complex (Fig. 2) indicates a weight loss of $3.94 \%$ (calcd $3.93 \%$ ) at a temperature range $178-218{ }^{\circ} \mathrm{C}$

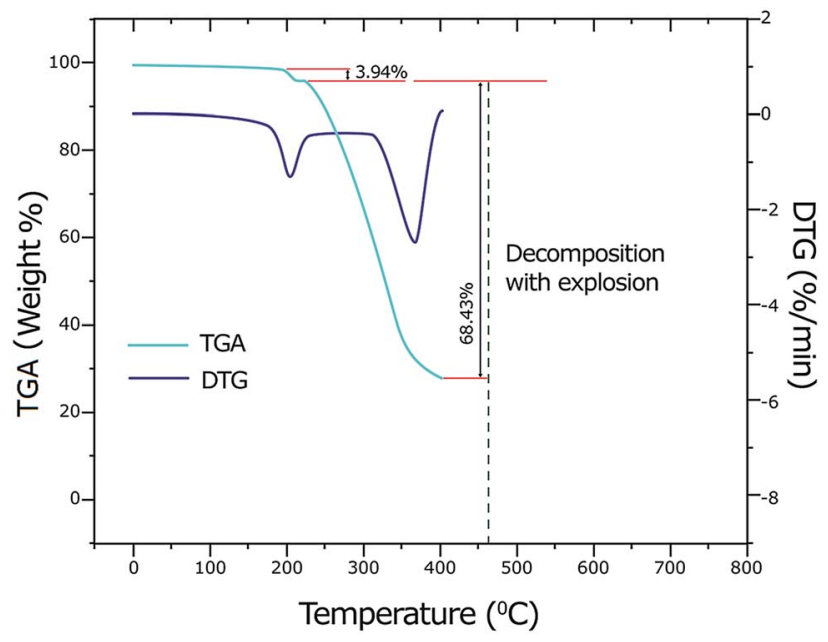

Fig. 2 TGA and DTG curves for copper(॥) complex.
$\left(\mathrm{DTG}_{\max }=201{ }^{\circ} \mathrm{C}\right)$ which corresponds to the removal of two coordinate water molecules. A weight loss of $68.43 \%$ (calcd $68.40 \%$ ) is observed in the temperature range $218-402{ }^{\circ} \mathrm{C}$ $\left(\mathrm{DTG}_{\max }=364{ }^{\circ} \mathrm{C}\right)$ which suggests the elimination of two ligands LC and Ibu-phen molecules. Further heating causes to decompose with explosion at $462{ }^{\circ} \mathrm{C}(735.15 \mathrm{~K})$. The explosion of the complexes containing perchlorate anion during the thermal decomposition was observed for other compounds such as $\left[\mathrm{Ca}\left(\mathrm{NH}_{3}\right)_{6}\right]\left(\mathrm{ClO}_{4}\right)_{2}, \quad\left[\mathrm{Sr}\left(\mathrm{OS}\left(\mathrm{CH}_{3}\right)_{2}\right)_{6}\right]\left(\mathrm{ClO}_{4}\right)_{2}, \quad\left[\mathrm{Mn}\left(\mathrm{NH}_{3}\right)_{6}\right]\left(\mathrm{ClO}_{4}\right)_{2}$, and $\left[\mathrm{Ca}\left(\mathrm{H}_{2} \mathrm{O}\right)_{4}\right]\left(\mathrm{ClO}_{4}\right)_{2}$ that the temperature of explosion changed from $540 \mathrm{~K}$ to above $700 \mathrm{~K} .^{60-62}$

\subsection{Antioxidant activity}

Oxidative stress results from an imbalance between two processes, one leading to reactive radical production and the other removing these species. Although these free radicals are formed during normal cellular functions in the body, their excess amount may play a crucial role in developing various diseases including cancer and chronic inflammation. Antioxidants can defense human health from reactive radicals and decrease oxidative stress.

In this part we discuss the antioxidant activity of free ligands and copper(II) complex evaluated in a series of in vitro assay involving $\mathrm{HO}^{\circ}$ radicals, $\mathrm{DPPH}^{\circ}$ radicals and $\mathrm{ABTS}^{{ }^{+}}$cation radicals. ${ }^{63-65}$ The results are shown in the Fig. $3-5$. The $\mathrm{IC}_{50}$ values of all samples including two ligands, copper(II) complex and ascorbic acid as a reference are summarized in the Table 2.

4.5.1. DPPH radical. The model of the scavenging of $\mathrm{DPPH}^{\circ}$ radicals is simple, rapid and this is considered as an appropriate method to study the antioxidant property of compounds. The $\mathrm{DPPH}^{\circ}$ radicals are generally stable except in

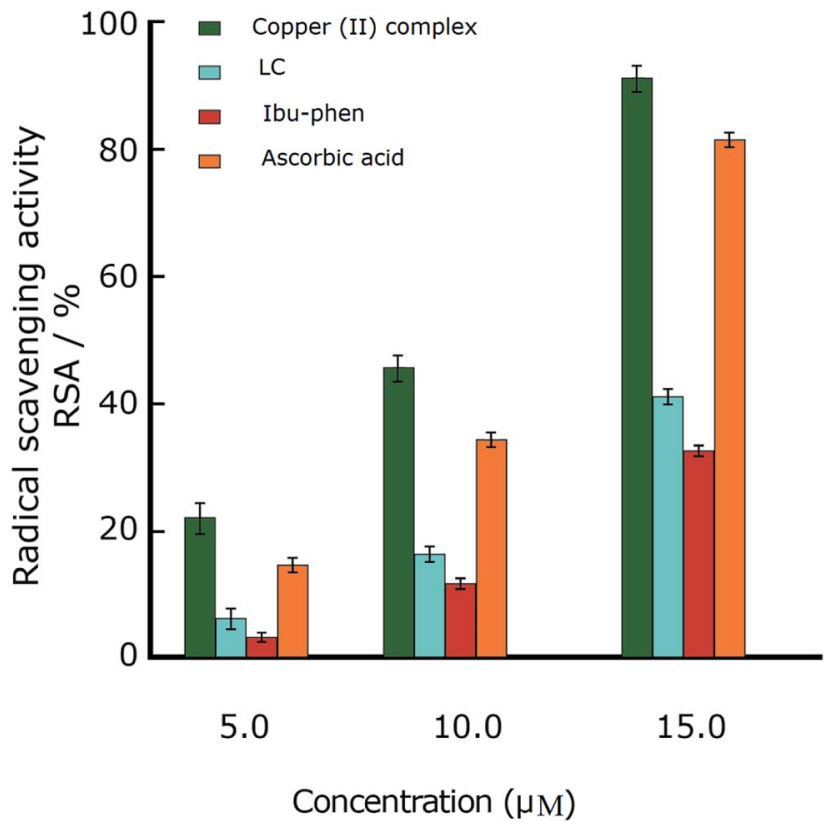

Fig. 3 Radical scavenging activity (RSA\%) of DPPH ${ }^{*}$. Comparison of different concentrations of LC, Ibu-phen, copper(II) complex and ascorbic acid. Data are shown as means $\pm \operatorname{SEM}(n=3)$. 


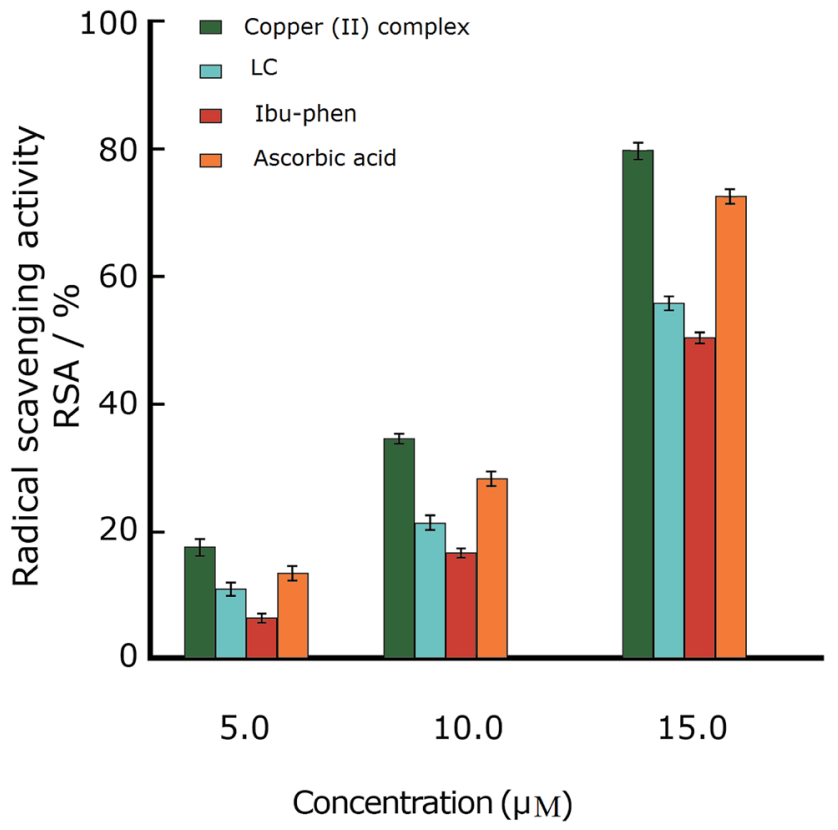

Fig. 4 Radical scavenging activity (RSA\%) of $\mathrm{ABTS}^{*}$. Comparison of different concentrations of LC, Ibu-phen, copper(II) complex and ascorbic acid. Data are shown as means $\pm \operatorname{SEM}(n=3)$.

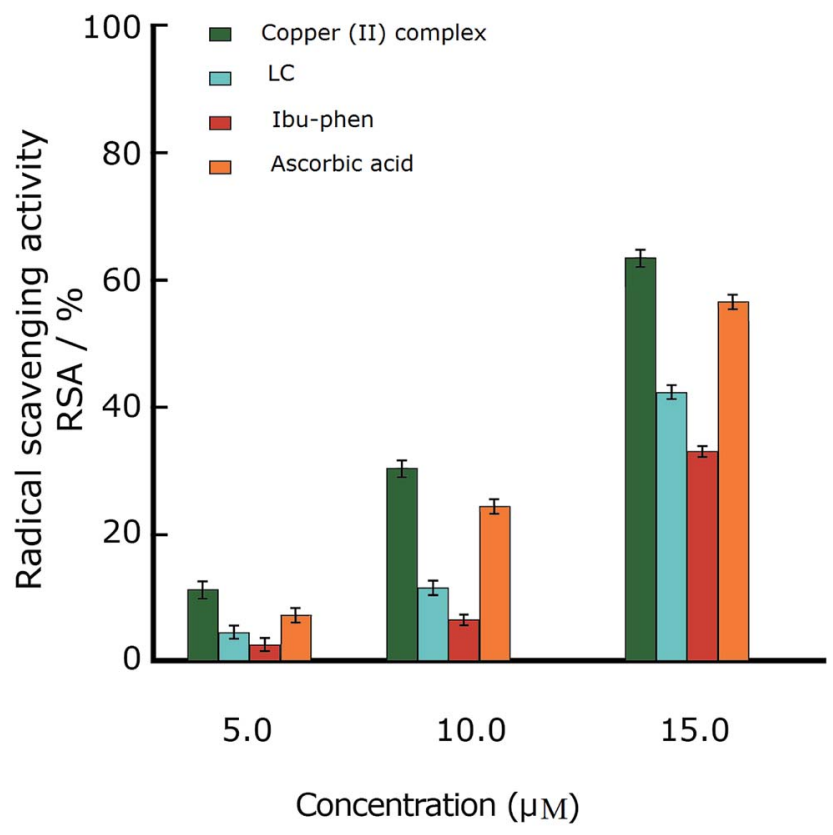

Fig. 5 Radical scavenging activity (RSA\%) of $\mathrm{OH}^{\circ}$. Comparison of different concentrations of LC, Ibu-phen, copper(II) complex and ascorbic acid. Data are shown as means $\pm \operatorname{SEM}(n=3)$.

the presence of compounds capable of donating hydrogen atoms, in which the radical sweep results a color change from purple to yellow. ${ }^{64}$

In the $\mathrm{DPPH}^{*}$ assay $(0.1 \mathrm{mM})$, the $\mathrm{IC}_{50}(50 \%$ concentration of inhibition for radical scavenging activity) values for LC, Ibuphen and copper(II) complex were found as 59.20, 63.20 and $1.21 \mu \mathrm{M}$, respectively. Under our reaction conditions $\mathrm{IC}_{50}$ value
Table 2 In vitro antioxidant activity of the free ligands and copper(II) complex

\begin{tabular}{lrrr}
\hline & \multicolumn{2}{c}{ Radical scavenging activities ${ }^{a}\left(\mathrm{IC}_{50}, \mu \mathrm{M}\right)$} \\
\cline { 2 - 4 } Samples & \multicolumn{1}{c}{$\mathrm{DPPH}^{*}$} & ABTS $^{+}$ & \multicolumn{1}{c}{$\mathrm{HO}^{\circ}$} \\
\hline LC & $59.20 \pm 0.10$ & $24.20 \pm 0.20$ & $54.30 \pm 0.10$ \\
Ibu-phen & $63.20 \pm 0.30$ & $27.30 \pm 0.10$ & $57.60 \pm 0.18$ \\
Copper(II) complex & $1.21 \pm 0.21$ & $2.92 \pm 0.10$ & $4.05 \pm 0.05$ \\
Ascorbic acid & $3.24 \pm 0.10$ & $3.84 \pm 0.15$ & $5.17 \pm 0.20$ \\
${ }^{a}$ IC $_{50}$ (50\% concentration of inhibition for radical scavenging activity). \\
Values are mean \pm SD of triplicates.
\end{tabular}

of ascorbic acid was $3.24 \mu \mathrm{M}$ (Table 2). Free radical scavenging activity (RSA) at various concentrations was decreased in the following order: copper(II) complex $>$ ascorbic acid $>$ LC $>$ Ibuphen (Fig. 3).

4.5.2. ABTS $^{*+}$

radical.

2,2'-Azino-bis-(3ethylbenzothiazoline-6-sulphonic acid) $\left(\mathrm{ABTS}^{\cdot+}\right)$ is also a free and stable radical cation. This radical is reactive towards most antioxidants such as phenols, thiols or compounds that can give a hydrogen atom or an electron. The $\mathrm{ABTS}^{{ }^{++}}$test is usually used to evaluate the antioxidant capacity of the biological fluids and many pure compounds.

Under these conditions, the blue $\mathrm{ABTS}^{*+}$ radical cation becomes colorless on reduction. This radical cation absorbs light at $734 \mathrm{~nm} .{ }^{17}$ In the $\mathrm{ABTS}^{\cdot+}$ assay $(1 \mathrm{mM})$, the $\mathrm{IC}_{50}$ values for LC, Ibu-phen, and Cu complex were found as 24.20, 27.30 and $2.92 \mu \mathrm{M}$, respectively. Under our reaction conditions, $\mathrm{IC}_{50}$ value of ascorbic acid is $3.84 \mu \mathrm{M}$ (Table 2). Thus, the RSA values at various concentrations were decreased in the following order: copper(II) complex $>$ ascorbic acid $>$ LC $>$ Ibu-phen (Fig. 4).

4.5.3. HO ${ }^{\circ}$ radical. Hydroxyl radical $\left(\mathrm{HO}^{\circ}\right)$ can damage virtually all types of macromolecules such as carbohydrates, nucleic acids, lipids and amino acids. Because of very short in vivo half-life (approximately $10^{-9}$ seconds), hydroxyl radical is very dangerous species to the organism compared with other free radicals. It attacks proteins, DNA, polyunsaturated fatty acid in membranes and most biological molecules. Therefore, the scavenging of this radical is one of the major aims of antioxidant administration. Hydroxyl radical is known to be capable of abstracting hydrogen atoms from membrane lipids and brings about peroxide reaction of lipids. ${ }^{64}$ The $\mathrm{IC}_{50}$ values of $\mathrm{HO}^{\bullet}$ radical scavenging assay $(1 \mathrm{mM})$ for $\mathrm{LC}$, Ibu-phen, and $\mathrm{Cu}$ complex were found as 54.30, 57.60 and $4.05 \mu \mathrm{M}$ respectively. Under the same conditions, $\mathrm{IC}_{50}$ value of ascorbic acid was 5.17 $\mu \mathrm{M}$ (Table 2). Thus, the RSA at various concentrations was decreased in the same order as for the $\mathrm{DPPH}^{\cdot}$ and $\mathrm{ABTS}^{\cdot+}$ : copper(II) complex $>$ ascorbic acid $>$ LC $>$ Ibu-phen (Fig. 5).

Overall, the antioxidant activity of the free ligands and copper(II) complex against the free radicals including $\mathrm{DPPH}^{*}$, ABTS $^{++}$and $\mathrm{HO}^{*}$ showed that the copper(II) complex displays greater scavenging activity than the free ligands. Moreover, the copper(II) complex shows much better scavenging activity than the standard antioxidant, ascorbic acid. Furthermore, the antioxidant activity of the copper(II) complex against the DPPH ${ }^{*}$ radical is better than $\mathrm{ABTS}^{\cdot+}$ and $\mathrm{OH}^{\cdot}$ radicals and the trend is 

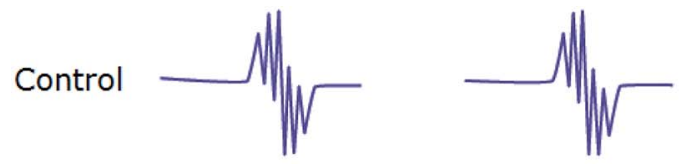

$5 \mu \mathrm{M}$

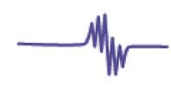

$15 \mu \mathrm{M}$
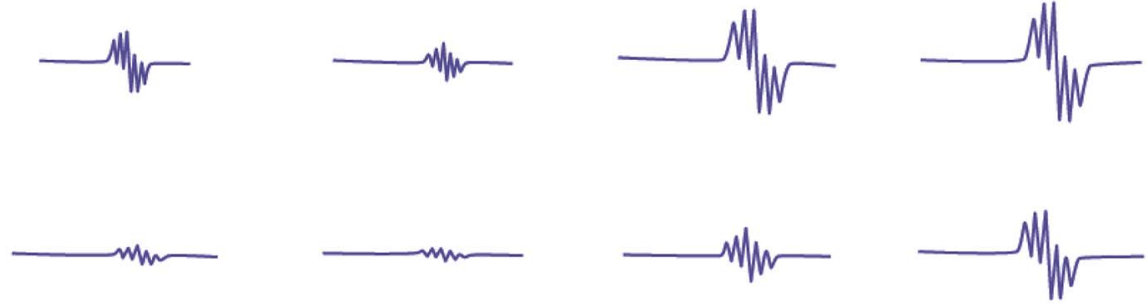

Ascorbic acid
Copper (II) complex
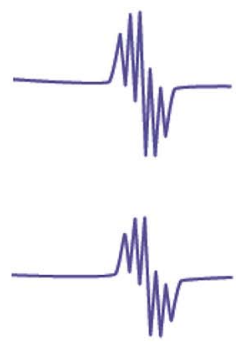

Ibu-phen

Fig. 6 EPR spectra of DPPH radical in the absence and presence (top) of LC, Ibu-phen, copper(॥) complex and ascorbic acid at 5 (middle) and 15 $\mu \mathrm{M}$ (bottom) concentrations.

decreased in the following order: $\mathrm{DPPH}^{*}>\mathrm{ABTS}^{*+}>\mathrm{HO}^{\circ}$. The low $\mathrm{IC}_{50}$ values obtained in the antioxidant assays confirm that the copper(II) complex could be a considerable example for the design of radical-quenching-based drugs.

The antioxidant activities of this copper complex against the $\mathrm{DPPH}^{*}$ and $\mathrm{ABTS}^{\cdot+}$ radicals are comparable with other copper complexes based on mixed 1,10-phenanthroline and coumarine ligands. ${ }^{66}$ The potent antioxidant activity of this copper(II) complex is probably related to the use of the ibuprofen amidephenanthroline ligand, known as antioxidant agents, and the coordination of these ligands to the copper center.

\subsection{Electron paramagnetic resonance (EPR) analysis for $\mathrm{DPPH}^{\circ}, \mathrm{ABTS}^{{ }^{+}}$and $\mathrm{HO}^{\circ}$ radicals scavenging assay}

Antioxidant activities of LC, Ibu-phen, copper(II) complex, and ascorbic acid were also tested for free radical sources by EPR spin trapping technique. During the addition of copper complex, the EPR signal is decreased as function of concentration, and scavenging pattern is dose-dependent. The copper complex and ascorbic acid scavenge $\mathrm{DPPH}^{-}$radical over about $91 \%$ and $89 \%$ at $15 \mu \mathrm{M}$, respectively, and the activity is decreased in the following order: copper(II) complex $>$ ascorbic acid $>$ LC > Ibu-phen (Fig. 6).

Copper(II) complex also quenches $\mathrm{ABTS}^{*+}$ radical and the scavenging ratio is $77 \%$ at $15 \mu \mathrm{M}$ that is comparable with ascorbic acid, i.e. 69\%, at the same concentration (Fig. 7).

Hydroxyl radicals generated in $\mathrm{Fe}^{2+} / \mathrm{H}_{2} \mathrm{O}_{2}$ system are trapped by DMPO forming spin adduct which can be detected by an EPR spectrometer. The typical $1: 2: 2: 1$ EPR signal of the DMPO$\mathrm{OH}$ adduct is clearly observed (Fig. 8). The ESR results show that copper(II) complex and ascorbic acid suppress about $66 \%$ and $62 \%$ of the hydroxyl radical at $15 \mu \mathrm{M}$, respectively. Antioxidant activity decreases in the following order: copper(II) complex > ascorbic acid $>$ LC $>$ Ibu-phen (Fig. 8).

EPR studies indicate that copper complex is the most potent scavenger of the $\mathrm{DPPH}^{*}, \mathrm{ABTS}^{*+}$ and $\mathrm{HO}^{*}$ radicals compared with ascorbic acid and free ligands. The scavenging activities of the $\mathrm{DPPH}^{\circ}, \mathrm{ABTS}^{\circ+}$ and $\mathrm{HO}^{\circ}$ radicals obtained by EPR spectroscopy are comparable with the results of UV-Vis study.

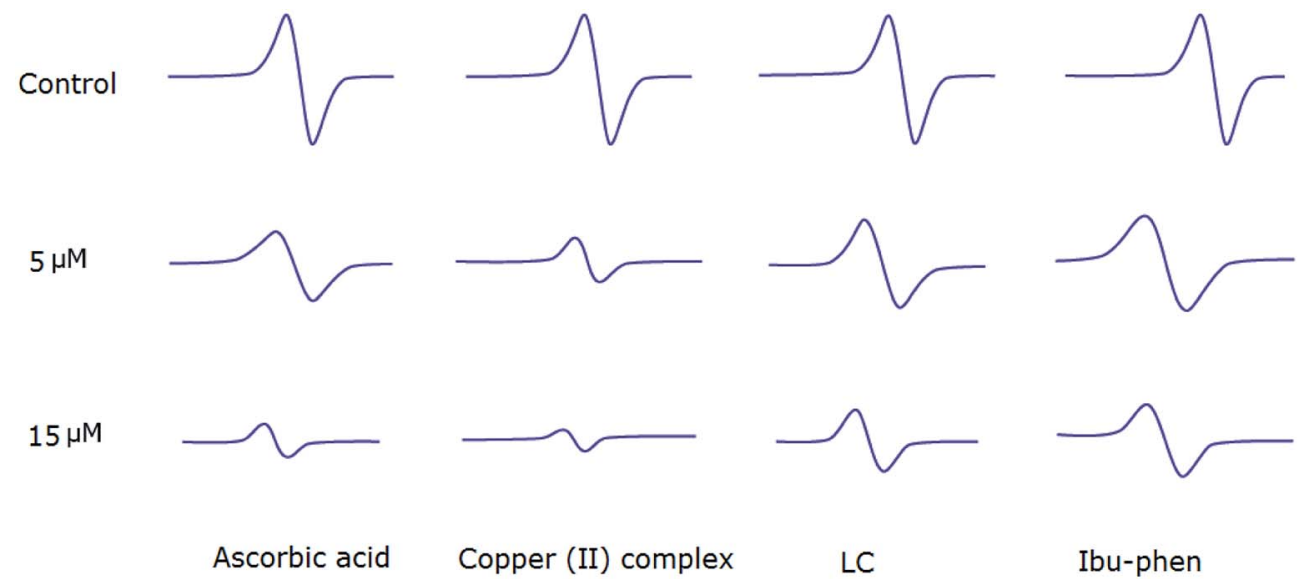

Fig. 7 EPR spectra of ABTS ${ }^{++}$radical in the absence and presence (top) of LC, Ibu-phen, copper(I) complex and ascorbic acid at 5 (middle) and 15 $\mu \mathrm{M}$ (bottom) concentrations. 


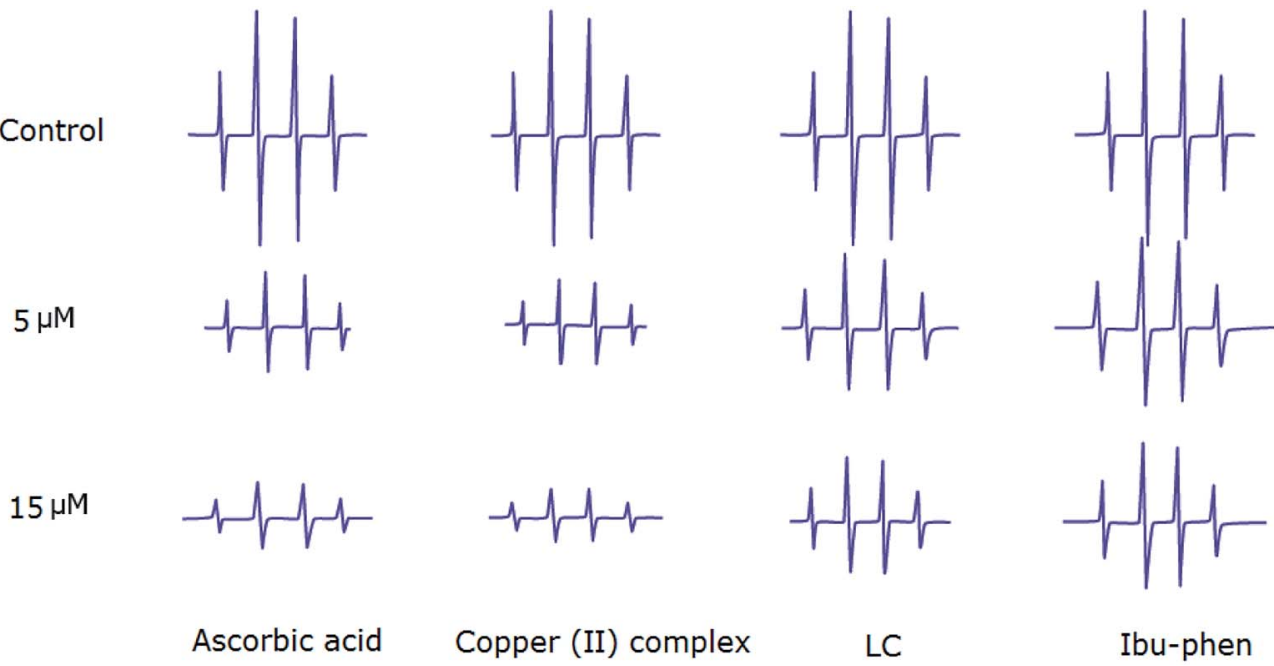

Fig. 8 EPR spectra of $\mathrm{HO}^{\circ}$ radical in the absence and presence (top) of LC, Ibu-phen, copper(॥) complex and ascorbic acid at 5 (middle) and 15 $\mu \mathrm{M}$ (bottom) concentrations.

\subsection{Mechanism of $\mathrm{DPPH}^{\bullet}$ radical scavenging assay by copper complex}

As the copper complex shows stronger radical scavenging activity towards $\mathrm{DPPH}^{*}$ than towards $\mathrm{ABTS}^{\cdot+}$ or $\mathrm{HO}^{*}$ radical, the scavenging mechanism of $\mathrm{DPPH}^{*}$ by copper(II) complex is chosen to be studied in details. The $\mathrm{DPPH}^{*}$ is characterized by an absorbance at $514 \mathrm{~nm}$ by UV-Vis. By adding the copper complex, the concentration of $\mathrm{DPPH}^{*}$ decreases following by the decrease of visible absorption band at $514 \mathrm{~nm}$. Meanwhile, by accepting one electron from copper(II) complex, the $\mathrm{DPPH}^{-}$ anion is formed and shows the absorption peak around $431 \mathrm{~nm} .{ }^{67,68}$ The intensity of the band at $431 \mathrm{~nm}$ increases as a function of the copper complex concentration up to $12 \mu \mathrm{M}$ which demonstrates the anion form of DPPH (Fig. 9). In the excess amount of copper(II) complex (14 to $16 \mu \mathrm{M}$ ), the band at $431 \mathrm{~nm}$ is disappeared due to the exchange of the anion form of $\mathrm{DPPH}^{-}$to DPPH-H. The DPPH-H is formed by accepting one proton from the copper complex. ${ }^{\mathbf{6 8 , 6 9}}$

This study suggests a two-step mechanism for the scavenging reaction of $\mathrm{DPPH}^{*}$ by copper(II) complex including the electron-accepting in the first and the proton-accepting in the second step.

\subsection{Computational study of antioxidant activity}

4.8.1. Optimized structures and electronic properties. Optimized geometries of copper(II) complex, Ibu-phen and LC investigated at the M05-2X/LanL2DZ level of theory are shown in Fig. 10. The $\mathrm{Cu}$ (II) ion is coordinated with the ligands by distorted octahedral geometry in which both Ibu-phen and LC act as bidentate ligands and two water molecules. The copper(II) complex structure wasoptimized using different spin multiplicities from 2, 6 and 8 to evaluate influence of its spin states on stabilization of the complex. As a result, the structure with doublet states (multiplicity being 2) was obtained with the lowest energy. Cartesians coordinates and molecular enthalpies of copper(II) complex with three multiplicity values are resumed in Table $\mathrm{S} 1$ of the ESI. $\dagger$

As can be seen in Fig. 10, Ibu-phen is coordinated to $\mathrm{Cu}$ (II) ion through its two nitrogen atoms, i.e. N53 and N54, while LC binds with the central cation via N56 and O55 atoms. The atomic distances of N53-Cu94 and N54-Cu94 are equal to 2.03 and $2.09 \AA$, while the atomic distances of N56-Cu94 and O55Cu94 are 1.99 and $2.13 \AA$, respectively. Moreover, the $\mathrm{Cu}(\mathrm{II})$ ion coordinates also with two water molecules with the distances of O98-Cu94 and O95-Cu94 equal to 2.26 and 2.38 A.

Molecular electrostatic potential consists in an efficient approach to find the reactive sites of a molecule for electrophilic and nucleophilic attacks. ${ }^{70,71}$ The reactive site consists in

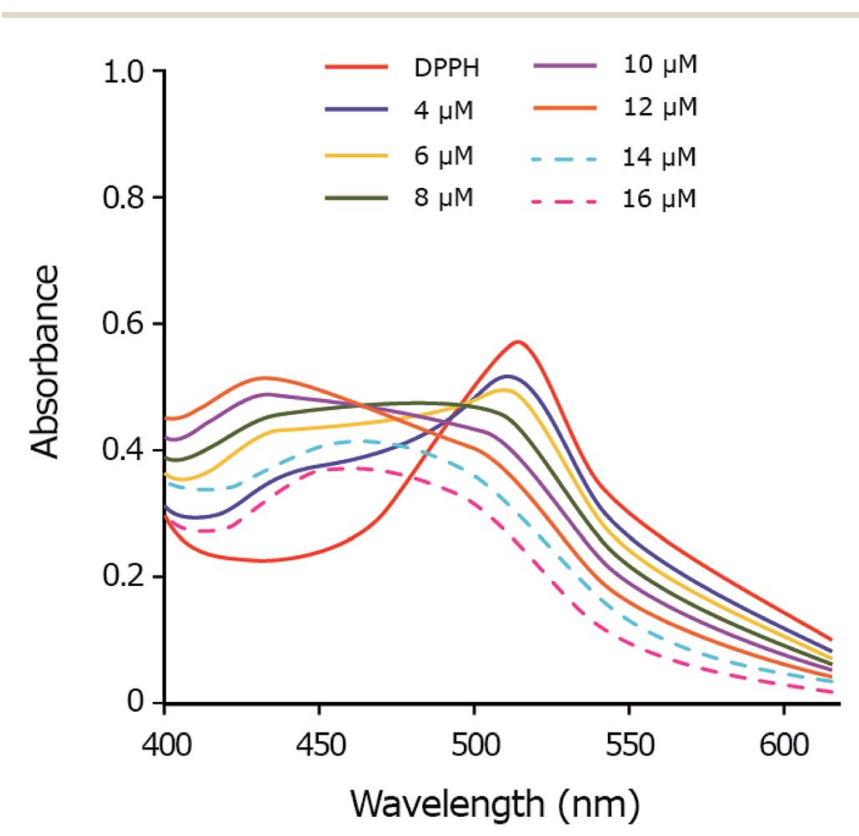

Fig. 9 UV-Vis spectral monitoring of reaction between DPPH ${ }^{*}(60 \mu \mathrm{M})$ and copper complex $(4-16 \mu \mathrm{M})$ in methanol: DMSO (99.5: 0.5). 


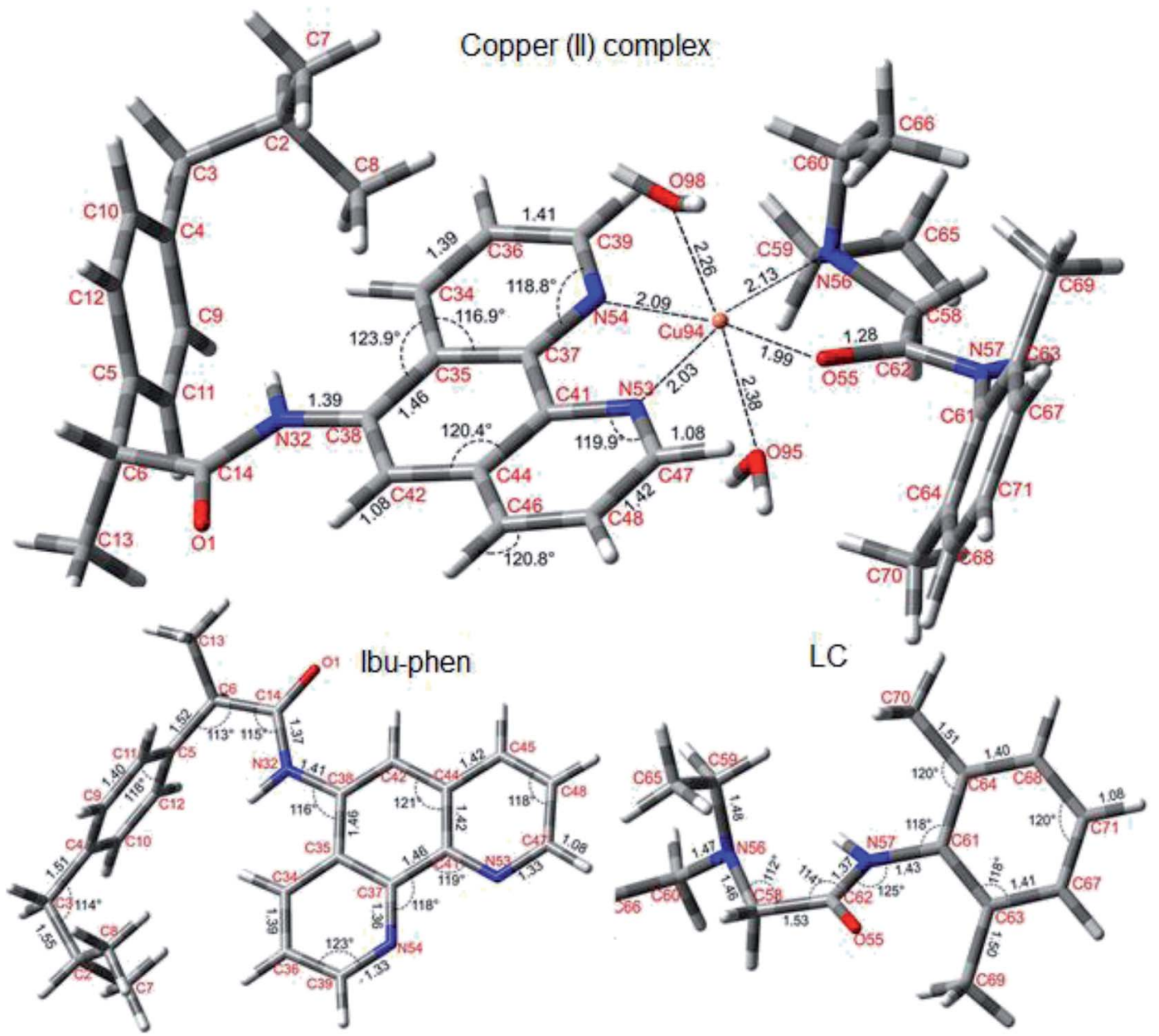

Fig. 10 Optimized structures of copper(॥) complex, Ibu-phen and LC ligands at the M05-2X/LanL2DZ level of theory.

partially charged regions of a molecule that have affinities for interacting with charged particles. The ESP maps of Ibu-phen, LC and copper(II) complex are displayed in Fig. 11A.

As can be observed in Fig. 11A, the most negative regions expressed in red color are located at the heteroatoms of the ligands, such as N53, N54 and O1 on Ibu-phen, or O55, N56 and N57 on lidocaine. This observation is also confirmed by natural population analysis (NPA) charges resumed in Table S2 of the ESI. $\dagger$

The highest occupied molecular orbital (HOMO) and the lowest unoccupied molecular orbital (LUMO) are two of the most important frontier orbitals which characterize the local reactivity of the studied compounds. ${ }^{72}$ The shapes of HOMO and LUMO of Ibu-phen, LC and the copper(II) complex are shown in Fig. 11B and C.

As observed in Fig. 11, the HOMO and LUMO for Ibu-phen are all distributed across the phenanthroline moiety, while for LC the HOMO is principally delocalized across the diethylamino substituent and its LUMO is concentrated at the phenyl ring. In case of the copper(II) complex, the HOMO is mainly localized at the Ibu-phen ligand and while its LUMO is distributed at the LC one. Moreover, the delocalized regions of the complex are essentially found at the phenyl moieties of the two ligands.
4.8.2. Natural bond orbital (NBO) analysis. The natural bond orbital of the copper(II) complex is also analyzed and the obtained results are presented in Table S3 of the ESI. $\dagger$ Generally, the Cu94 cation plays as an electron acceptor in coordinating with the two ligands and two water molecules.

In fact, electron density is essentially transferred from the first lone pair of electron on N53 atom, LP(1) N53, of Ibu-phen to the unoccupied orbitals on copper such as LP*(5) Cu94, LP*(6) Cu94 and $\mathrm{LP}^{*}(8) \mathrm{Cu} 94$ with lower stabilization energies of $120.2,49.6$ and $52.7 \mathrm{~kJ} \mathrm{~mol}^{-1}$, respectively. Similarly, the electron density is also donated from the first lone pair of electron from N54 atom, LP(1) N54, to the vacant orbitals on copper with lower stabilization energies from 37.1 to $98.9 \mathrm{~kJ} \mathrm{~mol}^{-1}$.

Regardless of the electron transfer from LC ligand, the electrons are donated from the $\sigma$ orbital on the N56-C59 bond, $\sigma(1)$ N56-C59, to the vacant orbital on $\mathrm{Cu}$ cation, LP*(9) Cu94, with a stabilization energy of $237.1 \mathrm{~kJ} \mathrm{~mol}^{-1}$. The first electron lone pairs located on N56 atom, LP(1) N56, are transferred to unoccupied orbitals on Cu94 cation, LP*(5) Cu94, LP*(6) Cu94 and $\mathrm{LP}^{*}(8) \mathrm{Cu} 94$, with energy values from 35.9 to $73.8 \mathrm{~kJ} \mathrm{~mol}^{-1}$. Moreover, the electrons are also donated from the lone pairs of electrons on 055 atom of LC, LP(1) O55 and LP(2) O55 and LP(3) $\mathrm{O} 55$, to the vacant orbitals on the Cu94 ion with lower stabilization energies from 26.2 to $395.8 \mathrm{~kJ} \mathrm{~mol}^{-1}$. 

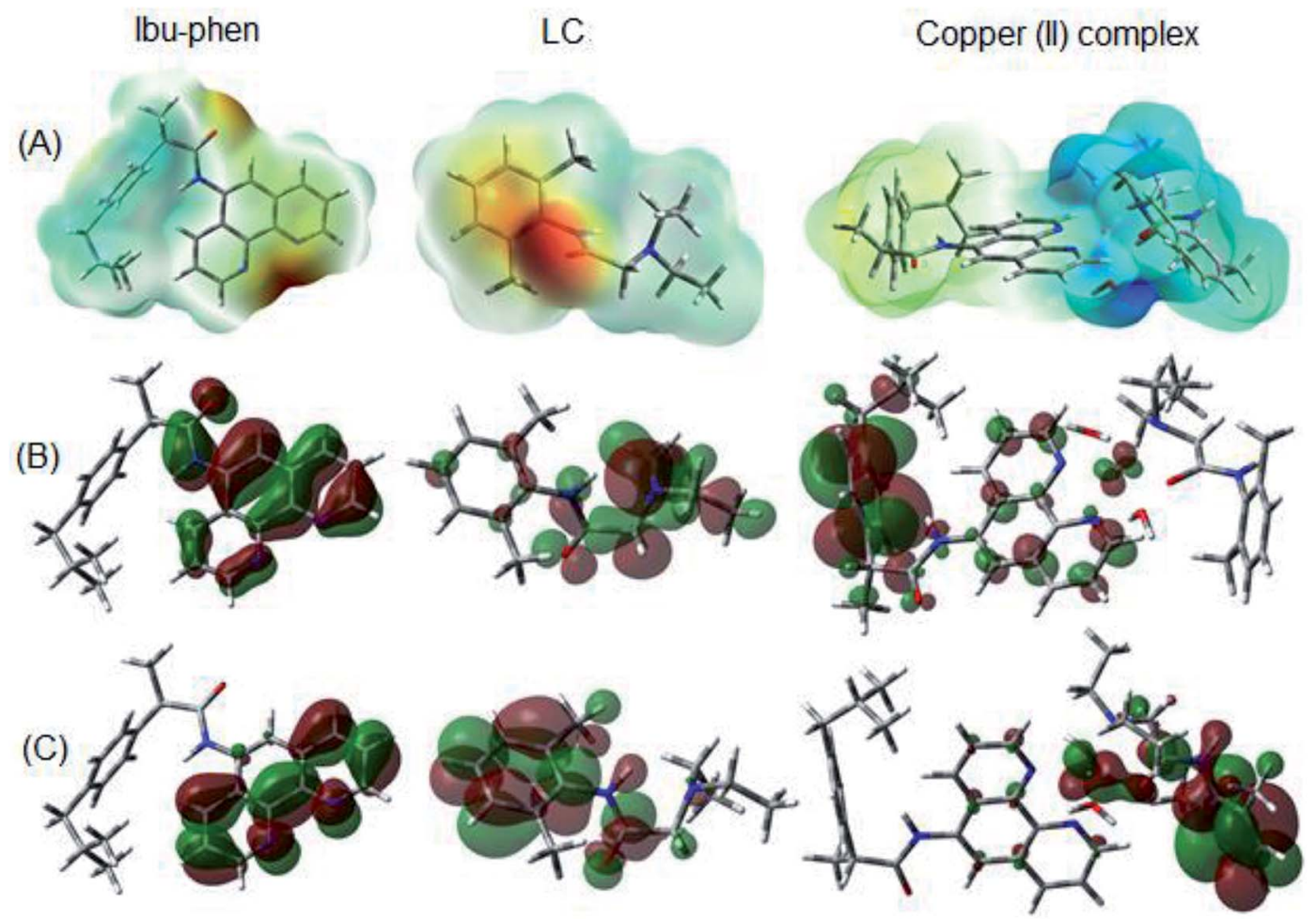

Fig. 11 (A) ESP maps, (B) HOMO and (C) LUMO distributions of Ibu-phen, LC ligands and copper(II) complex.

Two $\mathrm{H}_{2} \mathrm{O}$ molecules which are attached to the central $\mathrm{Cu}(\mathrm{II})$ ion also contribute their lone pairs of electrons to the vacant orbitals of the metal. Indeed, the second lone pairs of electrons on $\mathrm{O} 95$ atom, i.e. $\mathrm{LP}(2) \mathrm{O} 95$, and $\mathrm{O} 98$ one, i.e. $\mathrm{LP}(2) \mathrm{O} 98$, are donated to $\mathrm{LP}^{*}(9) \mathrm{Cu} 94$ with lower stabilization energies of 81.3 and $844.9 \mathrm{~kJ} \mathrm{~mol}^{-1}$, respectively. Thus, the existence of two water molecules improves significantly the stabilization of the copper(II) complex.

\subsection{Characteristic thermochemical properties for antioxidant activity}

4.9.1. Hydrogen transfer (HT) mechanism. Generally, antioxidant capacity of a compound via HT mechanism is characterized by its bond dissociation enthalpy (BDE) property (reaction (R1) and eqn (2)), the lower BDE value the higher antioxidant capacity via HT mechanism.

The lowest BDE values for Ibu-phen, LC and copper(II) complex calculated in the gas phase and in water solvent at the M05-2X/6-311++g(2df,2p)//M05-2X/LanL2DZ level of theory are resumed in Table 3.

For Ibu-phen, the $\mathrm{C} 6-\mathrm{H}$ bond located beside the $\mathrm{O} 1$ heteroatom has the lowest $\mathrm{BDE}$, i.e. $358.7 \mathrm{~kJ} \mathrm{~mol}^{-1}$ in the gas phase. While for LC ligand the easiest $\mathrm{H}$-atom donating site is found at the $\mathrm{C} 58-\mathrm{H}$ bond with $\mathrm{BDE}$ value being $354.6 \mathrm{~kJ} \mathrm{~mol}^{-1}$ in the gas phase. The corresponding BDE values of the copper(II) complex for the same positions on the two ligands are also calculated. As a result, BDE values are equal to 701.3 and $686.9 \mathrm{~kJ} \mathrm{~mol}^{-1}$ for the $\mathrm{C} 6-\mathrm{H}$ and $\mathrm{C} 58-\mathrm{H}$ bonds, respectively. Moreover, the lowest BDE value of copper(II) complex is found at the $\mathrm{C} 60-\mathrm{H}$ position with value being $596.3 \mathrm{~kJ} \mathrm{~mol}^{-1}$.
The same trend of activity is observed in water solvent with considerable decrease of all BDE values. For example, BDEs obtained in water at the $\mathrm{C} 6-\mathrm{H}$ position for Ibu-phen and copper(II) complex increase from 360.0 to $459.8 \mathrm{~kJ} \mathrm{~mol}^{-1}$, respectively. However, an inverse observation is noted for BDEs obtained in water for $\mathrm{C} 60-\mathrm{H}$ position which are equal to 364.0 and $305.6 \mathrm{~kJ} \mathrm{~mol}^{-1}$ for LC ligand and copper(II) complex, respectively.

Thus, the calculated data for $\mathrm{C} 60-\mathrm{H}$ position is in good agreement with the experimental one obtained from $\mathrm{DPPH}^{*}$ essay which indicates that the radical scavenging activity of copper(II) complex in the solvent is always higher than LC and Ibu-phen (Fig. 2).

4.9.2. Single electron transfer (SET) mechanism. Table 4 represents ionization energy (IE) and electron affinity (EA)

Table 3 The lowest BDE values $\left(\mathrm{kJ} \mathrm{mol}^{-1}\right)$ for $\mathrm{lbu}$-phen, LC and copper(II) complex calculated at the M05-2X/6-311++g(2df,2p)//M052X/LanL2DZ level of theory ${ }^{a}$

\begin{tabular}{llll}
\hline & \multicolumn{3}{l}{ Bond dissociation enthalpy, BDE $\left(\mathrm{kJ} \mathrm{mol}^{-1}\right)$} \\
\cline { 2 - 4 } Bond position & Ibu-phen & LC & Copper(II) complex \\
\hline Ibu-C2-H & 396.2 & & \\
Ibu-C3-H & 376.3 & & $701.3(459.8)$ \\
Ibu-C6-H & $\mathbf{3 5 8 . 7 ( 3 6 0 . 0 )}$ & & $686.9(350.5)$ \\
LC-C58-H & & $\mathbf{3 5 4 . 6}(339.6)$ & \\
LC-C59-H & & 366.9 & $\mathbf{5 9 6 . 3 ( 3 0 5 . 6 )}$ \\
LC-C60-H & & $365.5(364.0)$ &
\end{tabular}

${ }^{a}$ Values in parentheses correspond to BDE values obtained in water solvent. 
Table 4 IE and EA ( $\left.\mathrm{KJ} \mathrm{mol}^{-1}\right)$ for Ibu-phen, LC and copper(॥) complex calculated at the M05-2X/6-311++g(2df,2p)//M05-2X/LanL2DZ level of theory ${ }^{a}$

\begin{tabular}{llll}
\hline & Ibu-phen & LC & Copper(II) complex \\
\hline IE (eV) & $723.6(551.3)$ & $719.8(500.7)$ & $1105.7(647.3)$ \\
EA (eV) & $56.0(188.4)$ & $88.8(52.8)$ & $661.9(278.6)$
\end{tabular}

${ }^{a}$ Values in parentheses correspond to the results obtained in water solvent.

values obtained for Ibu-phen, LC and copper(II) complex calculated in the gas phase and in water solvent (reactions (R2), (R3) and equations eqn (5) and (6)) at the M05-2X/6$311++\mathrm{g}(2 \mathrm{df}, 2 \mathrm{p}) / / \mathrm{M} 05-2 \mathrm{X} / \mathrm{LanL} 2 \mathrm{DZ}$ level of theory.

As a result, IE and EA values in the gas phase for Ibu-phen are equal to 723.6 and $56.0 \mathrm{~kJ} \mathrm{~mol}^{-1}$, respectively. Meanwhile, these values for LC ligand are 719.8 and $88.8 \mathrm{~kJ} \mathrm{~mol}^{-1}$, respectively. The copper(II) complex has an increased IE value in the gas phase, i.e. $1105.7 \mathrm{~kJ} \mathrm{~mol}^{-1}$, being 1.5 -fold higher than the one of two ligands, while its EA value, i.e. $661.9 \mathrm{~kJ} \mathrm{~mol}^{-1}$, is 7- to 11-fold higher than the one of LC and Ibu-phen, respectively. The considerably higher EA value of copper(II) complex by compared with the ones of two ligands indicates its high antioxidant activity via the electron-accepting action. Thus, the antioxidant potential of the compounds can be classified in descending order: copper(II) complex > LC > Ibu-phen. This order is quite consistent with the results observed from $\mathrm{ABTS}^{+}$ essay (Fig. 3). The same trend is also observed in water solvent with the higher $\mathrm{EA}$ value of copper(II) complex, i.e. $278.6 \mathrm{~kJ} \mathrm{~mol}^{-1}$, by compared with the values of Ibu-phene and LC, i.e. 188.4 and $52.8 \mathrm{~kJ} \mathrm{~mol}^{-1}$, respectively.

Adiabatic reaction enthalpy $(\Delta H)$ and Gibbs free energy $(\Delta G)$ of SET reaction between the two ligands and copper(II) complex with different free radicals are also investigated. The electrondonating/-accepting reactions between the potential antioxidant (Anti) and free radicals $\left(\mathrm{R}^{\circ}\right)$ may occur as follows: ${ }^{65}$

$$
\begin{aligned}
& \text { Anti }+\left(\mathrm{R}^{\circ}\right) \rightarrow\left(\text { Anti }{ }^{-+}\right)+\left(\mathrm{R}^{-}\right) \\
& \text {Anti }+\left(\mathrm{R}^{\cdot}\right) \rightarrow\left(\text { Anti }{ }^{-}\right)+\left(\mathrm{R}^{+}\right)
\end{aligned}
$$

For reaction (R5), the adiabatic $\Delta H^{0}$ and $\Delta G^{0}$ values are calculated as follows:

$$
\Delta H_{\text {donor }}^{0}=\left[\mathrm{H}\left(\text { Anti }^{+}\right)+\mathrm{H}\left(\mathrm{R}^{-}\right)\right]-\left[\mathrm{H}(\text { Anti })+\mathrm{H}\left(\mathrm{R}^{\cdot}\right)\right]
$$

$$
\Delta G_{\text {donor }}^{0}=\left[\mathrm{G}\left(\text { Anti }^{\cdot+}\right)+\mathrm{G}\left(\mathrm{R}^{-}\right)\right]-\left[\mathrm{G}(\text { Anti })+\mathrm{G}\left(\mathrm{R}^{\cdot}\right)\right]
$$

Whereas for reaction (R6), the calculations are as follows:

$$
\begin{aligned}
& \Delta H_{\text {acceptor }}^{0}=\left[\mathrm{H}\left(\text { Anti }^{-}\right)+\mathrm{H}\left(\mathrm{R}^{+}\right)\right]-\left[\mathrm{H}(\text { Anti })+\mathrm{H}\left(\mathrm{R}^{\cdot}\right)\right] \\
& \Delta G_{\text {acceptor }}^{0}=\left[\mathrm{G}\left(\text { Anti }^{-}\right)+\mathrm{G}\left(\mathrm{R}^{+}\right)\right]-\left[\mathrm{G}(\text { Anti })+\mathrm{G}\left(\mathrm{R}^{\cdot}\right)\right]
\end{aligned}
$$

The free radicals considered for the above reactions include $\mathrm{HOO}^{\circ}, \mathrm{CH}_{3} \mathrm{OO}{ }^{\circ}, \mathrm{HO}^{\circ}, \mathrm{ABTS}^{\circ+}$ and $\mathrm{DPPH}^{\circ}$. The HOO and $\mathrm{CH}_{3} \mathrm{OO}{ }^{\circ}$ are chosen, because they are the simplest members of the peroxyl radicals (ROO') family which represent moderate reactivity and are suggested to be used for accurate prediction of rate constants for free radical scavenging processes. ${ }^{73}$ Whereas the $\mathrm{HO}^{\circ}, \mathrm{ABTS}^{\circ+}$ and $\mathrm{DPPH}^{*}$ radicals consist in the ones used in the experimental antioxidant capacity essays.

The reaction enthalpies $\left(\Delta H^{0}\right)$ and Gibbs free energies $\left(\Delta G^{0}\right)$ (in $\mathrm{kJ} \mathrm{mol}^{-1}$, at $298.15 \mathrm{~K}$ ) for the electron-donating/-accepting reactions ((R5) and (R6)) of the studied compounds and the free radicals calculated in the gas phase and in water solvent are all resumed in Tables 5 and 6, respectively.

On the basis of the results in Tables 5 and 6 , it can be noted that the electron-donating reactions in the gas phase for Ibuphen and LC are thermodynamically more favorable than the electron-accepting ones with two-fold lower values of $\Delta H^{0}$ and $\Delta G^{0}$. For example, $\Delta H^{0}$ of the reactions (R5) and (R6) between $\mathrm{HOO}^{\circ}$ and Ibu-phen increases from 632.2 to $1117.8 \mathrm{~kJ} \mathrm{~mol}^{-1}$, respectively, while $\Delta G^{0}$ value increases from 628.4 to $1118.0 \mathrm{~kJ} \mathrm{~mol}^{-1}$, respectively. However, for copper(II) complex, similar $\Delta H^{0}$ and $\Delta G^{0}$ value are obtained for the same reactions. Indeed, $\Delta H^{0}$ and $\Delta G^{0}$ values of reaction (R5) are equal to 1003.4 and $1004.3 \mathrm{~kJ} \mathrm{~mol}^{-1}$, respectively, while the ones of reaction (R6) are two-fold lower, 511.9 and $511.5 \mathrm{~kJ} \mathrm{~mol}^{-1}$, in turn.

In water solvent, the reaction enthalpies and Gibbs free energies are all strongly decreased because of the high solvation enthalpy of electron. And, the same trend is also found in water solvent with the higher $\Delta H^{0}$ and $\Delta G^{0}$ values of the electronaccepting reaction (R5) than the ones of the electron-donating reaction (R6). For example, the $\Delta H^{0}$ value of reactions (R5) and (R6) between copper(II) complex and $\mathrm{ABTS}^{\cdot+}$ in water solvent increases from 264.1 to $353.7 \mathrm{~kJ} \mathrm{~mol}^{-1}$, respectively (Table 5). These results indicate the higher electron-accepting

\begin{tabular}{|c|c|c|c|c|c|c|}
\hline \multirow[b]{2}{*}{ Free radical } & \multicolumn{3}{|c|}{$\underline{(\mathrm{R} 5): \text { Anti }+\left(\mathrm{R}^{*}\right) \rightarrow\left(\text { Anti }^{++}\right)+\left(\mathrm{R}^{-}\right)}$} & \multicolumn{3}{|c|}{$\underline{(\mathrm{R} 6):}$ Anti $+\left(\mathrm{R}^{*}\right) \rightarrow\left(\right.$ Anti $\left.^{-}\right)+\left(\mathrm{R}^{+}\right)$} \\
\hline & Ibu-phen & LC & Copper(II) complex & Ibu-phen & LC & Copper(II) complex \\
\hline $\mathrm{CH}_{3} \mathrm{OO}^{\circ}$ & $623.1(206.7)$ & $618.8(156.1)$ & $994.3(302.7)$ & $995.3(559.2)$ & $1140.3(694.8)$ & $389.4(469.0)$ \\
\hline $\mathrm{HO}^{\circ}$ & $565.9(104.9)$ & $561.7(54.2)$ & $937.2(200.9)$ & $1497.3(977.8)$ & $1642.3(1113.4)$ & $891.4(887.6)$ \\
\hline $\mathrm{ABTS}^{+}$ & $54.3(168.1)$ & $50.1(117.4)$ & $425.6(264.1)$ & $959.2(443.9)$ & $1104.1(579.5)$ & $353.2(353.7)$ \\
\hline
\end{tabular}
capacity of the studied compounds by compared to their electron-donating capacity which are coherent with the IE and EA data presented in Table 4.

Table 5 Reaction enthalpies $\left(\Delta H^{0}, \mathrm{~kJ} \mathrm{~mol}^{-1}\right)$ at $298.15 \mathrm{~K}$ for the reactions (R5) and (R6) between different radicals ( $\left.\mathrm{R}^{\circ}\right)$ and the potential antioxidants (Anti) in the gas phase, calculated at the M05-2X/6-311++g(2df,2p)//M05-2X/LanL2DZ level of theory ${ }^{a}$

${ }^{a}$ Values in parentheses correspond to the results obtained in water solvent. 
Table 6 Gibbs free energy $\left(\Delta G^{0}, \mathrm{~kJ} \mathrm{~mol}^{-1}\right)$ at $298.15 \mathrm{~K}$ for the reactions (R5) and (R6) between different radicals ( $\left.\mathrm{R}^{*}\right)$ and the potential antioxidants (Anti) in the gas phase, calculated at the M05-2X/6-311++g(2df,2p)//M05-2X/LanL2DZ level of theory ${ }^{a}$

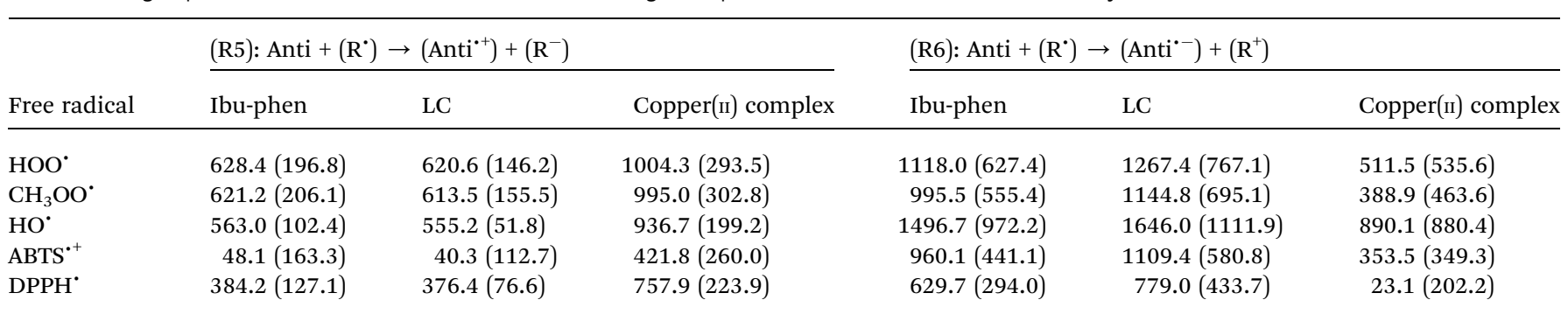

${ }^{a}$ Values in parentheses correspond to the results obtained in water solvent.

Furthermore, the electron-donating ability of the three studied compounds can be classified in descending order as follows: LC $\approx$ Ibu-phen $>$ copper(II) complex. For example, $\Delta H^{0}$ values of LC, Ibu-phen and copper(II) complex for reaction (R5) with $\mathrm{DPPH}^{\circ}$ radical in the gas phase are $385.1,389.4$ and $760.6 \mathrm{~kJ} \mathrm{~mol}^{-1}$, respectively, while $\Delta G^{0}$ values are $376.4,384.2$ and $757.9 \mathrm{~kJ} \mathrm{~mol}^{-1}$, in turn. The same trend is also found in water solvent with $\Delta H^{0}$ values of LC, Ibu-phen and copper(II) complex are equal to $78.5,129.2$ and $225.2 \mathrm{~kJ} \mathrm{~mol}^{-1}$, respectively (Table 5). The corresponding $\Delta G^{0}$ values are 76.6, 127.1 and $223.9 \mathrm{~kJ} \mathrm{~mol}^{-1}$, respectively (Table 6).

Conversely, the electron-accepting capacity of the considered compounds decreases in the following trend: copper(II) complex $>$ Ibu-phen $\approx$ LC. For example, $\Delta H^{0}$ values of reaction (R6) with $\mathrm{DPPH}^{*}$ radical in the gas phase are equal to 26.4, 632.3 and $777.3 \mathrm{~kJ} \mathrm{~mol}^{-1}$ for copper(II) complex, Ibu-phen and LC, respectively (Table 5). Similarly, $\Delta G^{0}$ values for the same reaction increase from $23.1 \mathrm{~kJ} \mathrm{~mol}^{-1}$ for copper(II) complex to $629.7 \mathrm{~kJ} \mathrm{~mol}^{-1}$ for Ibu-phen and $779.0 \mathrm{~kJ} \mathrm{~mol}^{-1}$ for LC (Table 6). The same results are obtained in water solvent.

This observation is consistent with the obtained results from $\mathrm{DPPH}^{\circ}, \mathrm{ABTS}^{\cdot+}$ and $\mathrm{HO}^{\circ}$ assays (Fig. $3-5$ ), and it agrees with the conclusion obtained from UV-Vis study (Section 4.7.) in which we proposed that copper(II) complex scavenges DPPH ${ }^{*}$ radical by accepting one electron and then one proton particle.

Moreover, in comparing the $\Delta H^{0}$ and $\Delta G^{0}$ values of the reactions between copper(II) complex with $\mathrm{DPPH}^{\circ}, \mathrm{ABTS}^{\circ+}$ and $\mathrm{HO}^{\circ}$ radicals in both the gas phase and water solvent, it can be seen that the reaction feasibility trend decreases in the following order: $\mathrm{DPPH}^{*}>\mathrm{ABTS}^{\circ+}>\mathrm{HO}^{*}$. This result is also in agreement with the experimental observations as discussed above (Table 2).

Finally, the results resumed in Tables 5 and 6 show that the electron transfer processes are strongly endogenic with highly positive values of reaction enthalpies and Gibbs free energies. While the electron-donating reactions (R5) are less endogenic than the electron-accepting ones (R6) for Ibu-phen and LC, the reaction (R6) for copper(II) complex is more endogenic than the reaction (R5).

4.9.3. Proton loss (PL) mechanism. Proton loss consists in the first step of the two-steps mechanisms including sequential proton loss electron transfer (SPLET) or proton coupled electron transfer (PCET). The difference of these mechanisms with the hydrogen transfer $(\mathrm{HT})$ one is that one proton $\left(\mathrm{H}^{+}\right)$and one electron $\left(\mathrm{e}^{-}\right)$are separately donated to free radical by different channels, while a single entity $\left(\mathrm{H}^{*}\right)$ is transferred in HT mechanism. ${ }^{74}$ The proton loss characterized by proton affinity (PA) acts as the initiation reaction in these two-steps mechanisms. For that reason, the PA values of the ligands as well as copper(II) complex are finally calculated in this study. In principal, the lower the PA value is, the higher the proton-donating ability of the studied compound possesses.

Table 7 resumes proton affinity (PA) values calculated for LC, Ibu-phen ligands and copper(II) complex in the gas phase and in water solvent at the M05-2X/6-311++g(2df,2p)//M05-2X/ LanL2DZ level of theory.

Generally, it can be seen that copper(II) complex possesses more remarkable proton-donating ability than the two ligands Ibu-phen and LC with lower PA values in both the gas phase and water solvent. Indeed, the lowest PA values in the gas phase of Ibu-phen found at the $\mathrm{C} 12-\mathrm{H}$ position is equal to $1398.5 \mathrm{~kJ} \mathrm{~mol}^{-1}$, whereas the PA of copper(II) complex calculated at the same position decreases to $1022.1 \mathrm{~kJ} \mathrm{~mol}^{-1}$. The lowest PA in the gas phase for LC ligand is equal to $1454.2 \mathrm{~kJ} \mathrm{~mol}^{-1}$ obtained at the $\mathrm{C} 65-\mathrm{H}$ position. This value is almost two times higher than the one of copper(II) complex calculated at the same position, i.e. $844.8 \mathrm{~kJ} \mathrm{~mol}^{-1}$, which consists also in the easiest proton donating position. Similarly, $\mathrm{PA}$ value calculated in water solvent at the $\mathrm{C} 65-\mathrm{H}$ position decreases from 461.8 to $336.8 \mathrm{~kJ} \mathrm{~mol}^{-1}$ for LC ligand and copper(II) complex, respectively.

Table 7 PA value ( $\mathrm{kJ} \mathrm{mol}^{-1}$ ) for LC, Ibu-phen ligands and copper(॥) complex in the gas phase at the M05-2X/6-311++g(2df,2p)//M05-2X/ LanL2DZ level of theory, (values in parentheses correspond to PA obtained in water solvent)

\begin{tabular}{llll}
\hline \multirow{2}{*}{$\begin{array}{l}\text { Proton donating } \\
\text { position }\end{array}$} & \multicolumn{2}{l}{ Proton affinity $\left(\mathrm{kJ} \mathrm{mol}^{-1}\right)$} & \\
\cline { 2 - 3 } & Ibu-phen & LC & Copper(II) complex \\
\hline Ibu-C11-H & 1401.0 & & 1014.6 \\
Ibu-C12-H & $\mathbf{1 3 9 8 . 5}(\mathbf{2 4 9 . 3 )}$ & $1022.1(226.8)$ \\
Ibu-C6-H & 1457.9 & & 1208.5 \\
Ibu-C13-H & 1401.0 & & \\
Ibu-N32-H & 1400.0 & & \\
LC-C65-H & & $\mathbf{1 4 5 4 . 2}(\mathbf{4 6 1 . 8})$ & $\mathbf{8 4 4 . 8}(\mathbf{3 3 6 . 8})$ \\
LC-C66-H & & 1456.0 & \\
LC-N57-H & & 1465.0 & \\
LC-C60-H & & 1460.6 & 856.9 \\
LC-C56-H & & 1531.1 &
\end{tabular}


Thus, it is observed that the lowest PA value of LC, Ibu-phen ligands and copper(II) complex is classified in decreasing order: LC > Ibu-phen > copper(II) complex with the values being 1454.2, 1384.5 and $856.9 \mathrm{~kJ} \mathrm{~mol}^{-1}$, respectively in the gas phase, and being 461.8, 249.3 and $226.8 \mathrm{~kJ} \mathrm{~mol}^{-1}$, respectively in water solvent. This result shows that the antioxidant activity via the proton-donating capacity of three studied compounds increases in the inverse trend: LC < Ibu-phen < copper(II) complex.

\section{Conclusion}

A new mononuclear copper(II) complex, $\left[\mathrm{Cu}(\mathrm{LC})(\mathrm{Ibu}-\mathrm{phen})\left(\mathrm{H}_{2^{-}}\right.\right.$ $\left.\mathrm{O})_{2}\right]\left(\mathrm{ClO}_{4}\right)_{2}$ (LC: lidocaine, Ibu-phen: ibuprofen amidephenanthroline), has been synthesized and characterized in order to study its antioxidant activity. The density functional theory (DFT) modeling was also investigated to characterize the structural and electronic properties of the ligands and copper(II) complex in the gas phase and water solvent at the M05-2X/6$311++\mathrm{g}(2 \mathrm{df}, 2 \mathrm{p}) / / \mathrm{M} 05-2 \mathrm{X} / \mathrm{LanL} 2 \mathrm{DZ}$ level of theory. ESP maps, NPA charge, HOMOs and LUMOs distributions and NBO analyses were systematically analyzed. Finally, the free radical scavenging activities in both media via hydrogen transfer (HT), single electron transfer (SET) and proton loss (PL) mechanisms were also computed by calculating the characterizing thermochemical properties such as BDE, IE, EA and PA quantities. The findings are multiple:

(i) Structural characterization by FT-IR spectroscopy, elemental analysis, thermogravimetric analysis and mass spectrometry shows that the ligands LC, Ibu-phen and two $\mathrm{H}_{2} \mathrm{O}$ molecules coordinate with $\mathrm{Cu}(\mathrm{II})$ ion in distorted octahedral geometry in which $\mathrm{O}$ and $\mathrm{N}$ atoms of the ligands are bound to the copper ion. The structure of copper(II) complex and the coordination environment around $\mathrm{Cu}(\mathrm{II})$ center were also confirmed by EPR and UV-Vis spectroscopy.

(ii) Optimized structure of copper(II) complex and ligands are calculated. ESP maps and NPA charge distributions analysis demonstrate the highly negative charges found on the heteroatoms including N53, N54 atoms of Ibu-phen and O55 and N56 atoms of LC which favor the ligands to bind with the Cu94 ion.

(iii) Frontier molecular orbitals analyses indicate that HOMO for copper(II) complex is mainly localized at Ibu-phen ligand, while its LUMO is distributed at LC ligand. Moreover, the delocalized regions of the complex are essentially found at the phenyl moieties of two ligands. The natural bond orbital (NBO) analyses also show the electron-accepting role of the central $\mathrm{Cu}(\mathrm{II})$ ion in coordinating with the ligands and water molecules.

(iv) The EPR spin trapping technique was also used to evaluate the antioxidant activities of LC, Ibu-phen, copper(II) complex and ascorbic acid for various free radicals including $\mathrm{DPPH}^{\circ}, \mathrm{ABTS}^{\cdot+}$ and HO${ }^{\circ}$. The obtained results show that the free radicals scavenging potential of the studied species is decreased as follows: copper(II) complex > ascorbic acid > LC > Ibu-phen. All the $\mathrm{DPPH}^{\circ}, \mathrm{ABTS}^{\cdot+}$ and $\mathrm{HO}^{*}$ radicals scavenging assays also confirm this trend.

(v) The UV-Vis spectroscopies were investigated for the $\mathrm{DPPH}^{*}$ scavenging assay by copper(II) complex to evaluate thoroughly the reaction mechanism. The obtained results allow us to propose that copper(II) complex scavenges $\mathrm{DPPH}^{*}$ radical by a two-steps mechanism in which the radical accepts one electron and then one proton particle from the copper complex. This result is in agreement with computational calculations for single electron transfer (SET) mechanism.

(vi) Bond dissociation enthalpy (BDE) values of the compounds under study were calculated in the gas phase and water solvent to evaluate HT mechanism. It can be seen that the lowest BDE values of copper(II) complex in water solvent are lower than the ones of Ibu-phen and LC. This result is in good agreement with the experimental results from $\mathrm{DPPH}^{\circ}$ antioxidant assays.

(vii) Electron-donating and -accepting reactions of the ligands and copper(II) complex with some representative radicals including $\mathrm{HOO}^{\circ}, \mathrm{CH}_{3} \mathrm{OO}^{\circ}, \mathrm{HO}^{\circ}, \mathrm{ABTS}^{\circ+}$ and $\mathrm{DPPH}^{\circ}$ were considered in both media. It is shown that copper(II) complex displays considerably higher radical scavenging activity than the ligands via its electron-accepting capacity. This activity decreases in the following trend: copper(II) complex > Ibu-phen $\approx$ LC. Moreover, the reactivity of copper(II) complex with different radicals decreases in the following order: $\mathrm{DPPH}^{*}>$ ABTS $^{+}>\mathrm{HO}^{\circ}$. This result agrees with the experimental observations.

(viii) Proton affinity calculation demonstrates that the proton loss ability of copper(II) complex is considerably higher than the one of Ibu-phen and LC ligands, which is coherent with the experimental observation from $\mathrm{DPPH}^{\bullet}$ radical essays as well as UV-Vis spectroscopies results.

The present experimental and computational studies may hopefully contribute an effort towards the development of metallodrugs as potent antioxidants agents based on copper(II) complex.

\section{Author contributions}

The manuscript was written through contributions of all authors. All authors have given approval to the final version of the manuscript.

\section{Conflicts of interest}

The authors declare no competing financial interest.

\section{Abbreviations}

LC Ibu-phen Ibuprofen amide-phenanthroline ROS Reactive oxygen species

ABTS 2,2'-Azinobis(3-ethylbenzthiazoline-6-sulphonic acid)

DPPH 2,2-Diphenyl-1-picrylhydrazyl

DIEA $\quad N, N$-Diisopropylethylamine

EDC-HCl $\quad N$-(3-Dimethylaminopropyl)- $N$-ethylcarbodiimide hydrochloride

HOBt $\cdot x \mathrm{H}_{2} \mathrm{O}$ 1-Hydroxybenzotriazole hydrate

HOMO Highest occupied molecular orbital 


$\begin{array}{ll}\text { LUMO } & \text { Lowest unoccupied molecular orbital } \\ \text { HT } & \text { Hydrogen transfer } \\ \text { BDE } & \text { Bond dissociation enthalpy } \\ \text { IE } & \text { Ionization energy } \\ \text { EA } & \text { Electron affinity } \\ \Delta H & \text { Adiabatic reaction enthalpy } \\ \Delta G & \text { Gibbs free energy } \\ \text { NBO } & \text { Natural bond orbital } \\ \text { SET } & \text { Single electron transfer } \\ \text { PL } & \text { Proton loss } \\ \text { PA } & \text { Proton affinity } \\ \text { ZPE } & \text { Zero-point vibrational energy } \\ \text { EPR } & \text { Electron paramagnetic resonance } \\ \text { TGA } & \text { Thermogravimetric analysis } \\ \text { DTG } & \text { Differential thermogravimetric analysis } \\ \text { calcd } & \text { Calculated }\end{array}$

\section{Acknowledgements}

The authors acknowledge general support from the School of Chemistry, National University of Ireland (NUI), Galway. The authors are also grateful to the Gridchem (https:// www.seagrid.org) for allocating computer times. This program used the Extreme Science and Engineering Discovery Environment (XSEDE) facilities that are supported by USA National Science Foundation grant number ACI-10535. DQD thanks also Dr N. T. Le Anh for her useful scientific discussions and her support during the revision of manuscript.

\section{References}

1 A. Barzegar and A. A. Moosavi-Movahedi, PLoS One, 2011, 6, e26012.

2 F. Ahmadinejad, S. Geir Møller, M. HashemzadehChaleshtori, G. Bidkhori and M.-S. Jami, Antioxidants, 2017, 6, 51-66.

3 L. Rochette, J. Lorin, M. Zeller, J.-C. Guilland, L. Lorgis, Y. Cottin and C. Vergely, Pharmacol. Ther., 2013, 140, 239257.

4 R. Castañeda-Arriaga, A. Pérez-González, M. Reina, J. R. Alvarez-Idaboy and A. Galano, J. Phys. Chem. B, 2018, 122, 6198-6214.

5 A. Galano and J. Raúl Alvarez-Idaboy, Int. J. Quantum Chem., 2018, e25665, DOI: 10.1002/qua.25665.

6 M. M. Kasprzak, A. Erxleben and J. Ochocki, RSC Adv., 2015, 5, 45853-45877.

7 V. A. Kostyuk, A. I. Potapovich, E. N. Vladykovskaya, L. G. Korkina and I. B. A. Afanas'ev, Arch. Biochem. Biophys., 2001, 385, 129-137.

8 R. Prajapati, S. K. Dubey, R. Gaur, R. K. Koiri, B. K. Maurya, S. K. Trigun and L. Mishra, Polyhedron, 2010, 29, 1055-1061.

9 L. G. Korkina, E. A. Ostrachovich, G. A. Ibragimova and I. B. Afanas'ev, Presented in Part at the Trace Elements in Man and Animals 10, Evian, France, 1999.

10 M. M. Kasprzak, L. Szmigiero, E. Zyner and J. Ochocki, J. Inorg. Biochem., 2011, 105, 518-524.
11 S. B. Bukhari, S. Memon, M. Mahroof-Tahir and M. I. Bhanger, Spectrochim. Acta, Part A, 2009, 71, 1901-1906.

12 M. Jiménez and F. García-Carmona, J. Agric. Food Chem., 1999, 47, 56-60.

13 A. Pękal, M. Biesaga and K. Pyrzynska, BioMetals, 2011, 24, 41-49.

14 A.-H. Yang, X.-Y. Shi, X. Li, F.-F. Li, Q.-Q. Zhang, S.-X. Jiang, J.-Z. Cui and H.-L. Gao, RSC Adv., 2014, 4, 25227-25233.

15 J. M. Dimitric Marković, Z. S. Markovic, I. A. Pasti, T. P. Brdaric, A. Popovic-Bijelic and M. Mojovic, Dalton Trans., 2012, 41, 7295-7303.

16 I. Kostova and S. Balkansky, Curr. Med. Chem., 2013, 20, 4508-4539.

17 I. Ejidike and P. Ajibade, Molecules, 2015, 20, 9788-9802.

18 R.-K. Pan, G.-B. Li, S.-G. Liu, X.-P. Zhou and G.-Z. Yang, Monatsh. Chem., 2016, 147, 1189-1196.

19 D. Senthil Raja, G. Paramaguru, N. S. P. Bhuvanesh, J. H. Reibenspies, R. Renganathan and K. Natarajan, Dalton Trans., 2011, 40, 4548-4559.

20 S. Sathiyaraj, K. Sampath, R. J. Butcher, R. Pallepogu and C. Jayabalakrishnan, Eur. J. Med. Chem., 2013, 64, 81-89.

21 S. C. Sahoo, R. Kataria and S. K. Mehta, in Chemical Drug Design, ed. K. G. Girish and K. Vinod, De Gruyter, Berlin, Boston, 2016, pp. 215-242, DOI: 10.1515/9783110368826012.

22 T. You-Zhi, L. Zai-Qun and W. Di, J. Biochem. Mol. Toxicol., 2009, 23, 81-86.

23 L. Tabrizi and H. Chiniforoshan, Polyhedron, 2016, 119, 575583.

24 L. Tabrizi, P. McArdle, A. Erxleben and H. Chiniforoshan, Eur. J. Med. Chem., 2015, 103, 516-529.

25 L. Tabrizi and H. Chiniforoshan, Invest. New Drugs, 2016, 34, 723-732.

26 L. Tabrizi and H. Chiniforoshan, BioMetals, 2017, 30, 59-70.

27 L. Tabrizi, Dalton Trans., 2017, 46, 7242-7252.

28 R. Bushra and N. Aslam, Oman Med. J., 2010, 25, 155-1661.

29 C. Senthil, V. Sandeep, S. Neetika and S. Manu, Med. Chem., 2013, 9, 1006-1016.

30 E. Valeur and M. Bradley, Chem. Soc. Rev., 2009, 38, 606-631. 31 M. Wettasinghe and F. Shahidi, Food Chem., 2000, 70, 17-26.

32 J. C. Pennycooke, S. Cox and C. Stushnoff, Environ. Exp. Bot., 2005, 53, 225-232.

33 H. Wu, J. Zhu, W. Diao and C. Wang, Carbohydr. Polym., 2014, 113, 314-324.

34 F. Nanjo, K. Goto, R. Seto, M. Suzuki, M. Sakai and Y. Hara, Free Radical Biol. Med., 1996, 21, 895-902.

35 L.-Y. Zang, G. Cosma, H. Gardner and V. Vallyathan, BBA, Biochim. Biophys. Acta, Gen. Subj., 1998, 1425, 469-477.

36 M. J. Frisch, G. W. Trucks, H. B. Schlegel, G. E. Scuseria, M. A. A. Robb, J. R. Cheeseman, G. Scalmani, V. Barone, B. Mennucci, G. A. Petersson, H. Nakatsuji, M. Caricato, X. Li, H. P. Hratchian, A. F. Izmaylov, J. Bloino, G. Zheng, J. L. Sonnenberg, M. Hada, M. Ehara, K. Toyota, R. Fukuda, J. Hasegawa, M. Ishida, T. Nakajima, Y. Honda, O. Kitao, H. Nakai, T. Vreven, J. A. Montgomery Jr, J. E. Peralta, F. Ogliaro, M. J. Bearpark, J. Heyd, E. N. Brothers, K. N. Kudin, V. N. Staroverov, R. Kobayashi, 
J. Normand, K. Raghavachari, A. P. Rendell, J. C. Burant, S. S. Iyengar, J. Tomasi, M. Cossi, N. Rega, N. J. Millam, M. Klene, J. E. Knox, J. B. Cross, V. Bakken, C. Adamo, J. Jaramillo, R. Gomperts, R. E. Stratmann, O. Yazyev, A. J. Austin, R. Cammi, C. Pomelli, J. W. Ochterski, R. L. Martin, K. Morokuma, V. G. Zakrzewski, G. A. Voth, P. Salvador, J. J. Dannenberg, S. Dapprich, A. D. Daniels, Ö. Farkas, J. B. Foresman, J. V. Ortiz, J. Cioslowski and D. J. Fox, Gaussian 09 E.01, Gaussian, Inc., Wallingford, CT, USA, 2015.

37 Y. Zhao, N. E. Schultz and D. G. Truhlar, J. Chem. Theory Comput., 2006, 2, 364-382.

38 L. E. Roy, P. J. Hay and R. L. Martin, J. Chem. Theory Comput., 2008, 4, 1029-1031.

39 W. Chen, S. Sun, W. cao, Y. Liang and J. Song, J. Mol. Struct., 2009, 918, 194-197.

40 A. Abkari, I. Chaabane and K. Guidara, Phys. E, 2016, 81, 136-144.

41 A. E. Reed, L. A. Curtiss and F. Weinhold, Chem. Rev., 1988, 88, 899-926.

42 J. E. Bartmess, J. Phys. Chem., 1994, 98, 6420-6424.

43 E. Cancès, B. Mennucci and J. Tomasi, J. Chem. Phys., 1997, 107, 3032-3041.

44 Z. Marković, J. Tošović, D. Milenković and S. Marković, Comput. Theor. Chem., 2016, 1077, 11-17.

45 D. Q. Dao, T. C. Ngo, N. M. Thong and P. C. Nam, J. Phys. Chem. B, 2017, 121, 9348-9357.

46 T. C. Ngo, D. Q. Dao, M. T. Nguyen and P. C. Nam, RSC Adv., 2017, 7, 39686-39698.

47 H. Chiniforoshan, L. Tabrizi, M. Hadizade, M. R. Sabzalian, A. N. Chermahini and M. Rezapour, Spectrochim. Acta, Part A, 2014, 128, 183-190.

48 K. Binnemans, P. Lenaerts, K. Driesen and C. GorllerWalrand, J. Mater. Chem., 2004, 14, 191-195.

49 S. Chandra and Vandana, Spectrochim. Acta, Part A, 2014, 129, 333-338.

50 S. Chandra, S. Bargujar, R. Nirwal and N. Yadav, Spectrochim. Acta, Part A, 2013, 106, 91-98.

51 B. de Bruin, E. Bill, E. Bothe, T. Weyhermüller and K. Wieghardt, Inorg. Chem., 2000, 39, 2936-2947.

52 C. F. G. C. Geraldes, M. P. M. Marques, B. Castro and E. Pereira, Eur. J. Inorg. Chem., 2000, 2000, 559-565.

53 N. M. El-Metwally and G. A. A. Al-Hazmi, Spectrochim. Acta, Part A, 2013, 107, 289-295.
54 M. Massacesi, G. Ponticelli, V. B. Addepali and V. G. Krishnan, J. Mol. Struct., 1978, 48, 55-62.

55 M. Massacesi, G. Ponticelli, V. Buddha Addepalli and V. G. Krishnan, J. Mol. Struct., 1979, 51, 27-36.

56 M. S. S. Babu, K. H. Reddy and P. G. Krishna, Polyhedron, 2007, 26, 572-580.

57 K. G. Dutton, G. D. Fallon and K. S. Murray, Inorg. Chem., 1988, 27, 34-38.

58 B. J. Hathaway and D. E. Billing, Coord. Chem. Rev., 1970, 5, 143-207.

59 G. Świderski, M. Kalinowska, I. Rusinek, M. Samsonowicz, Z. Rzączyńska and W. Lewandowski, J. Therm. Anal. Calorim., 2016, 126, 1521-1532.

60 J. Hetmańczyk, Ł. Hetmańczyk, A. Migdał-Mikuli and E. Mikuli, J. Therm. Anal. Calorim., 2014, 118, 1049-1056.

61 A. Migdał-Mikuli and J. Hetmańczyk, J. Therm. Anal. Calorim., 2008, 91, 529-534.

62 A. Migdał-Mikuli, E. Szostak and P. Bernard, J. Therm. Anal. Calorim., 2014, 115, 443-449.

63 X. Yao, L. Zhu, Y. Chen, J. Tian and Y. Wang, Food Chem., 2013, 139, 59-66.

64 N. Söylemez, E. Yabas, S. Sahin-Bolukbasi and M. Sülü, J. Porphyrins Phthalocyanines, 2018, 22, 233-242.

65 A. Martínez, R. Vargas and A. Galano, J. Phys. Chem. B, 2009, 113, 12113-12120.

66 J. C. Patel, H. R. Dholariya, K. S. Patel and K. D. Patel, Appl. Organomet. Chem., 2012, 26, 604-613.

67 J. A. Weil and G. A. Janusonis, J. Org. Chem., 1962, 27, 12481250.

68 Q. U. Ain, U. Ashiq, R. A. Jamal and M. Mahrooof-Tahir, Spectrochim. Acta, Part A, 2013, 115, 683-689.

69 I. Nakanishi, T. Kawashima, K. Ohkubo, H. Kanazawa, K. Inami, M. Mochizuki, K. Fukuhara, H. Okuda, T. Ozawa, S. Itoh, S. Fukuzumi and N. Ikota, Org. Biomol. Chem., 2005, 3, 626-629.

70 I. B. Obot, D. D. Macdonald and Z. M. Gasem, Corros. Sci., 2015, 99, 1-30.

71 E. Scrocco and J. Tomasi, in Advances in Quantum Chemistry, ed. P.-O. Löwdin, Academic Press, 1978, vol. 11, pp. 115-193.

72 D. Q. Dao, T. D. Hieu, T. Le Minh Pham, D. Tuan, P. C. Nam and I. B. Obot, J. Mol. Model., 2017, 23, 260.

73 A. Galano and J. R. Alvarez-Idaboy, J. Comput. Chem., 2013, 34, 2430-2445.

74 L. Muñoz-Rugeles, A. Galano and J. Raúl Alvarez-Idaboy, Phys. Chem. Chem. Phys., 2017, 19, 6969-6972. 